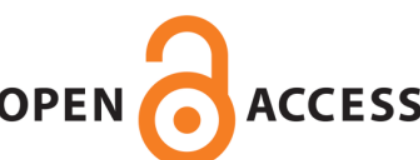

OPEN ACCESS

UWS Academic Portal

\title{
Effect of bipolar plate materials on performance of fuel cells
}

Wilberforce, Tabbi; ljaodola, Oluwatosin; Ogungbemi, Emmanuel; El Hassan, Zaki;

Thompson, James; Olabi, Abdul G.

Published in:

Reference Module in Materials Science and Materials Engineering

DOI:

10.1016/B978-0-12-803581-8.11272-X

Published: 24/12/2018

Document Version

Peer reviewed version

Link to publication on the UWS Academic Portal

Citation for published version (APA):

Wilberforce, T., ljaodola, O., Ogungbemi, E., El Hassan, Z., Thompson, J., \& Olabi, A. G. (2018). Effect of bipolar plate materials on performance of fuel cells. In M. S. J. Hashmi (Ed.), Reference Module in Materials Science and Materials Engineering (pp. 1-15). Elsevier Inc.. https://doi.org/10.1016/B978-0-12-803581-8.11272$\mathrm{X}$

\section{General rights}

Copyright and moral rights for the publications made accessible in the UWS Academic Portal are retained by the authors and/or other copyright owners and it is a condition of accessing publications that users recognise and abide by the legal requirements associated with these rights.

\section{Take down policy}

If you believe that this document breaches copyright please contact pure@uws.ac.uk providing details, and we will remove access to the work immediately and investigate your claim. 


\section{Provided for non-commercial research and educational use. Not for reproduction, distribution or commercial use.}

This article was originally published in Reference Module in Materials Science and Materials Engineering, published by Elsevier, and the attached copy is provided by Elsevier for the author's benefit and for the benefit of the author's institution, for non-commercial research and educational use including without limitation use in instruction at your institution, sending it to specific colleagues who you know, and providing a copy to your institution's administrator.

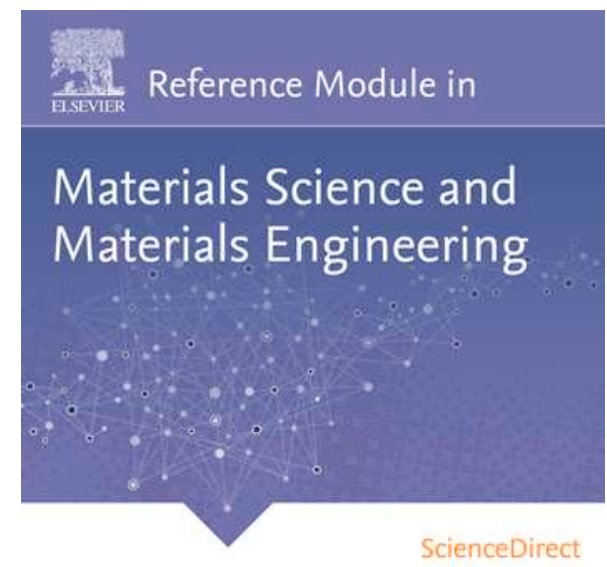

All other uses, reproduction and distribution, including without limitation commercial reprints, selling or licensing copies or access, or posting on open internet sites, your personal or institution's website or repository, are prohibited.

For exceptions, permission may be sought for such use through Elsevier's permissions site at:

http://www.elsevier.com/locate/permissionusematerial

Tabbi Wilberforce, Oluwatosin Ijaodola, Emmanuel Ogungbemi, Zaki El Hassan, James Thompson and Abdul G. Olabi Effect of Bipolar Plate Materials on Performance of Fuel Cells. In: Saleem Hashmi (editor in chief), Reference Module in Materials Science and Materials Engineering. Oxford: Elsevier, 2018, pp. 1-15.

ISBN: 978-0-12-803581-8.

(C) 2018 Elsevier Inc. All rights reserved. 


\section{Effect of Bipolar Plate Materials on Performance of Fuel Cells}

Tabbi Wilberforce, Oluwatosin ljaodola, Emmanuel Ogungbemi, Zaki El Hassan, and James Thompson, University of the West of Scotland, Hamilton, United Kingdom

Abdul G Olabi, Aston University, Birmingham, United Kingdom and University of Sharjah, Sharjah, United Arab Emirates

(C) 2018 Elsevier Inc. All rights reserved.

\begin{tabular}{llr}
\hline $\mathbf{1}$ & Introduction & 1 \\
$\mathbf{2}$ & Bipolar Plates and Their Material Properties & 2 \\
$\mathbf{3}$ & Polymer Composite Plates & 3 \\
3.1 & Polymers & 4 \\
3.1 .1 & Thermosets & 5 \\
3.1 .2 & Thermoplastics & 5 \\
3.1 .3 & Method of molding & 5 \\
3.1 .4 & Fillers & 6 \\
3.1 .5 & Non-porous graphite \\
3.1 .5 .1 & Graphite & 6 \\
3.1 .5 .2 & Expanded graphite (EG) & 6 \\
3.1 .5 .3 & Carbon fibers (CF) & 6 \\
3.1 .5 .4 & Carbon black (CB) & 7 \\
3.1 .5 .5 & Carbon nanotubes (CNT) & 8 \\
3.1 .5 .6 & Graphene & 8 \\
3.2 & Characteristics of Composite BP & 9 \\
$\mathbf{4}$ & Metals & 9 \\
$\mathbf{5}$ & Conclusion & 10 \\
Reference & & 11 \\
\hline
\end{tabular}

\section{Introduction}

The recent increase in world population has resulted in high demand of energy. Fossil fuel continue to dominate the energy industry, but unstable prices of fossil commodities coupled with other factors has compelled the research community to consider other alternative to fossil products. The reliance of fossil fuel as a means of energy generation has negative effect on the environment. Recent climate change is attributed to the dependency on fossil products as energy generation medium. Renewable energy sources are today considered as a key replacement of fossil product in futuristic terms. They are often highly abundant with no or less emissions of toxic and harmful substances into the environment. During off peak periods, most renewable energy systems still produce power which goes to waste due to lack of enough energy storage mediums or technologies. These losses affect the running cost of most renewable energy systems prompting the need for new and efficient method of storing these excess energies. Electrolyzers as well as electrochemical device are today viewed as the remedy to these challenges. Excess energy produced during off peak times dissociate water molecules to hydrogen and oxygen via electrolytic process. Using an electrochemical device (e.g., Fuel cell), the hydrogen can then be used to generate electricity for other applications when the need arises. This important application of fuel cells are contributing factors leading to the sudden surge in research conducted for the development of fuel cells. They are friendly to the environment with less or no release of harmful substances into the environment [1]. The research community is currently performing several experiments to reduce the overall carbon dioxide emissions into the atmosphere. Several countries have initiated policies that seeks to hasten the accomplishment of the hydrogen age with the recent Paris Climate Accord being a practical example [2]. There are several kinds of fuel cells but the PEM Fuel cells has currently become a keen research area because of their operational characteristics and material composition. They are very conducive for portable applications and automotive purposes. Proton Exchange Membrane fuel cells functions between temperatures of $60-80^{\circ} \mathrm{C}[3]$. The main reactive substances for PEMFC are hydrogen and oxygen/air. The byproduct of the electrochemical reaction is heat and water. Fuel cells have three main parts. The components in a fuel cell are MEA, current collectors and the BP. Weight of the fuel cell is determined by bipolar plate material composition. More than $80 \%$ of the fuel cell mass is attributed to the BP whiles nearly $50 \%$ of fuel cell prices is determined by the price of the BP [4-6]. The reactive substance enters the cell via the BP. Distribution of reactive substances on the catalyst layer uniformly is determined by the bipolar plate. Removal of excess heat and water from the cell is controlled based on the nature of the bipolar plate [7]. Electrons released after electrochemical reaction converge on the bipolar plate. Using current collectors, these negatively charged ions then flow via any external circuit connected to the fuel cell. Due to the reactive gases being volatile, the bipolar plate serves as a seal for the fuel cell to prevent the easy escape of the reacting species [6]. Development of fuel cell BP is becoming a critical aspect of research in the fuel cell industry. Today, materials that are less expensive, easy to machine and easily accessible are being considered via experimental investigation for 
manufacturing of fuel cell BP. The types of materials used in the production of bipolar plate is categorized into electro graphite, metals and polymers [7]. The types of materials used in manufacturing BP for PEM fuel cells have been reviewed by other researchers [8]. Properties of some materials for manufacturing BP was also reported by Wang et al. [8] A combination of some of these chemical and physical characteristics of these materials have resulted in the evolution of other novel materials suitable for PEM fuel cell bipolar plate production. This investigation explores some of these novel materials in terms of their performance on fuel cells based on their individual physical characteristics. The Department of Energy, US, stipulates that for fuel cell bipolar plate to be suitable for automotive applications and portable applications, they must have excellent electrical and thermal conductivity. Again, their permeability must be good. The BP must further withstand shocks. In terms of mechanical strength, they must not break easily. When exposed to harsh environmental conditions, bipolar plates should be able to resist any form of corrosion. The flow plate should finally be cheap and affordable. The electrical conductivity should be more than $100 \mathrm{~S} \mathrm{~cm}{ }^{-1}$ as well as the interfacial contact resistance being less than $30 \mathrm{~m} \Omega \mathrm{cm}^{2}$ [9-15]. Their stability chemically in slightly acidic water pH should also be more than 4 . The corrosion resistance should be less than $16 \mu \mathrm{A} \mathrm{cm}^{-2}$ [15]. Their thermal conductivity must exceed $10 \mathrm{~W}(\mathrm{~m} \mathrm{~K})^{-1}$. It must also be less permeable to hydrogen and oxygen $\left(2 \times 10^{-6} \mathrm{~cm}^{3}\left(\mathrm{~cm}^{2} \mathrm{~s}\right)^{-1}\right.$. It is required that their flexural strength is more than $59 \mathrm{MPa}$ and their impact strength more than $40.5 \mathrm{Jm}^{-1}$ [16]. Traditional fuel cells often have their bipolar plate made up of graphite. This is because graphite allows the easy flow of electricity and heat. Again, the chemical stability of graphite is good. Graphite as a material has some limitations as well. They are generally expensive and have high volume, reducing their viability for commercial purposes. Today, materials that are cheap with less volume is being investigated by researchers around the world to produce BP $[17,18]$. Mechanical strength for graphite is low and sometimes tedious working with graphite. This implies that manufacturing BP using graphite is not economical hence increase the overall cost of the fuel cell [19-23]. These setbacks using graphite for bipolar plate production has necessitated the need for the research community to explore other materials like metals. Metals in general have high strength mechanically, support easy flow of electrons, does not allow the easy flow of gas through them, less expensive and can be manufactured easily [24-27]. Stampability and thickness plate reduction of nearly $1 \mathrm{~mm}$ are some advantages of bipolar plates made of metals. Several research today is geared towards using stainless steel as material for manufacturing BP. Stainless steel (SS) is made up of a passive film which aid in reducing the possibility of corrosion of the entire material. The passive film has a thickness of 1-3 nm and this is dependent on the steel grade and the environment. The passive film raises the ICR higher between the BP as well as the carbon even though it reduces the rate of corrosion of stainless steel [27]. Stainless steel used in fuel cells go through passivation. The various components in the stainless steel will determine the thickness. Other factors like the composition of the passive film, environment $\mathrm{pH}$, potential being applied and ions in an aqueous state affects the thickness of the stainless steel [28]. Again, the passive film will break down and reform in the slightest change in the environment causing metallic ions to be released leading to contamination. The low cost of polymer carbon composite bipolar plates has attracted a number of researchers into their viability as a bipolar plate material. They also have low weight and their corrosion resistance ability is higher than graphite or metallic bipolar plates [28]. Non - stampability, low electrical and mechanical properties are well known demerits of composites bipolar plates. A novel bipolar plate suitable for fuel cells for commercial applications must have the characteristics of metals, graphite and composites combined together. Today, scientists are adopting various means of making this a reality to reduce corrosions on metals and prevent the passive layer developed on surfaces of metals that leads to low power being generated and increase the possibility of the catalytic and electrolytic layers being contaminated [27]. This review further intends to delve into metallic plates with strong mechanical strength as flow plates for fuel cells. Some parameters like weight and volume must be considered first for any bipolar plate to be accepted for fuel cells. A detailed information on the performance of using bipolar plate made of metals and that made of composite materials is still not covered very much in literature hence the motivation for this review. Other researchers like Tibbetts et al. [28] investigated on materials suitable for flow plate. Their investigation covered several kinds of composite properties as well as methods of fabricating a vapor - grown carbon nanofiber/polymer composites. Other researchers also made review papers on coating, material and fabrications of the membrane electrode assembly as well as composite, graphitic and metal flow plates [29]. Material composition as well as processes for the fabrication of flow plates made up of metals has also been investigated thoroughly in literature [30]. The strength and easy electrical characteristics of graphite has also been published by another researcher [31].

\section{Bipolar Plates and Their Material Properties}

Fig. 1 depicts the various activities in a fuel cell leading to the generation of current. It is made up of anode and cathode backing and membrane electrode assembly. The bipolar plates have several functions. Below are some of the functions of the flow plates. They aid in easy dissemination of the reactive gases on the MEA. BP helps in water management of the fuel cell. They are also good for the separation of individual cell stack and aid in transmitting current from one cell to the other. Thermal management in the fuel cell is also conducted with the help of the bipolar plates [32]. The physical and chemical properties for each material for the manufacture of bipolar plates differ as shown in Table 1.

There are other vital physical characteristics of bipolar plate materials and these are: They must have good coefficient of thermal expansion, density and hydrophobicity. According to Borup and Vanderborgh [33] and Cooper [34], in order for a material to be classified as suitable for a BP it must conform to certain characteristics. Electrical conductivity of the material should be very good and have a plate resistance less than $0.01 \mathrm{~cm}^{2}$. Again, the material must support the easy flow of heat out of the cell and gas permeability of the material must also be less than $10^{-4} \mathrm{~cm}^{3} / \mathrm{s} \mathrm{cm}^{2}$. The material should also be corrosion resistant, having a 


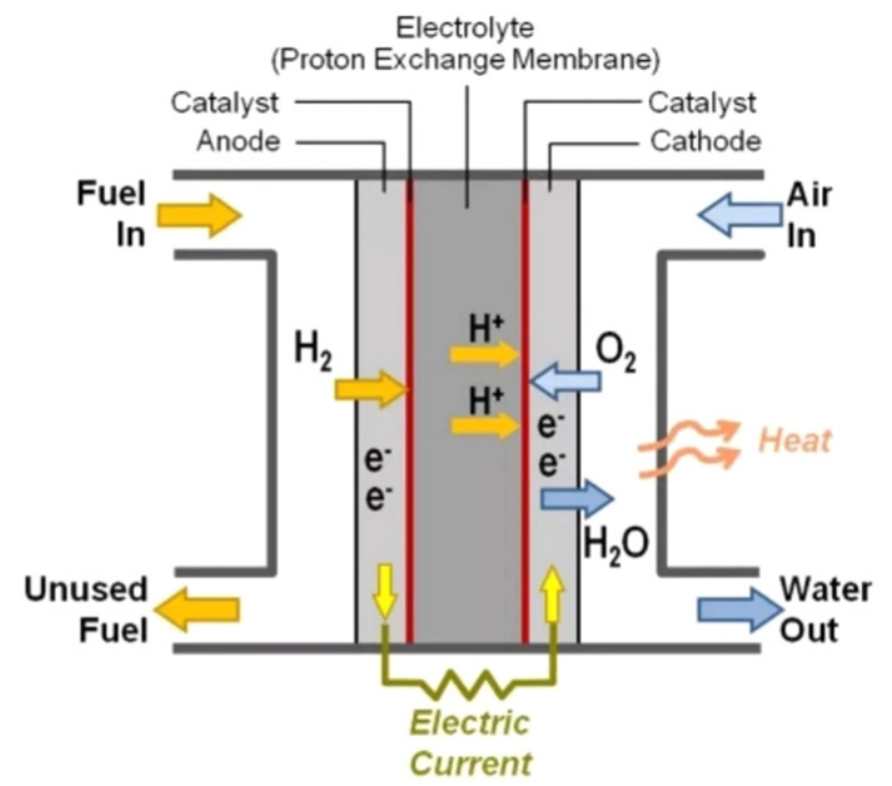

Fig. 1 Electrochemical processes in a fuel cell. Authorization to reproduce obtained from ref Wilberforce, T., Alaswad, A., Palumbo, A., Olabi, A. G., 2016. Advances in stationary and portable fuel cell applications. International Journal of Hydrogen Energy 41 (37).

Table 1 Various characteristic of materials for bipolar plates

\begin{tabular}{ll}
\hline Bipolar plate function & Chemical property \\
\hline Dissemination and maintenance of hydrogen and oxygen as well as residual gases and & $\begin{array}{l}\text { Pervious to hydrogen, ability to resist electrochemical } \\
\text { deterioration }\end{array}$ \\
liquids & Electrically conductive \\
Conduct electric current & Thermally conductive \\
Aiding in heat removal & Mechanical strength \\
Separation of cells in the stack & ald \\
\hline
\end{tabular}

corrosion rate less than $0.016 \mathrm{~mA} / \mathrm{cm}^{2}$. Strength of the material must also be greater than $22 \mathrm{Ib} / \mathrm{in}^{2}$ and finally the density of the material must be less than $5 \mathrm{gm} / \mathrm{cm}^{2}$. Flow plate materials are categorized into Non - metals, Metals and Composite. Fig. 2 shows various materials used as flow plates in cell stacks.

Materials suitable for flow plates are largely classified into metals and carbon-based. The research and development activities and some applications are all geared towards carbon - based flow plates because their densities are very high especially graphite [29]. This is mainly due to the characteristics observed for PEM fuel cells even when operated in bad conditions, but usage of graphite in PEM fuel cells was purposely for laboratory works and stationary applications where the weight of the bipolar plate as well as the volume being low was not considered. Designing of flow channels on these materials is very expensive and the material is also brittle hence discouraging its usage in most terrestrial applications and other applications like the mobile and automotive industry. The transportation field normally prefers cheap mass production processes [26-39]. Metals with the exception of noble metals is mostly preferred especially by the research community due to their easy flow of heat and electricity, low gas permeation, and simple when machining flow channels on them. Their chemical instability in harsh corrosive conditions as found in PEM fuel cells remains the major setbacks for most metallic bipolar plates as this normally leads to their surfaces becoming corroded as well as the formation of thin oxide layer on the surfaces of these metallic materials. This often lead to poisoning especially in the solid polymer electrolyte and even the catalyst layer through the release of corrosion by products $\left(\mathrm{Fe}^{3+}, \mathrm{Cr}^{2+}, \mathrm{Ni}^{2+}\right)$. This can cause the ICR between the metallic plates and the GDL layers to increase appreciably leading to depletion in the performance of the cell stack. Several investigations conducted in recent times are geared towards enhancing resistance to electrochemical deterioration as well as interfacial contact resistance of metal flow plates. Some of these strategies involves the usage of a protective layer which is very conductive but very thin on the surfaces of these metals. Different researchers have made several publications on the specific material and processes suitable for the manufacturing of bipolar plates [40-42].

\section{Polymer Composite Plates}

Another material used as bipolar plate material is composite materials. Composites are very light in weight. It is easy for them to be shaped into any specific size and this makes them suitable for PEMFCs. They are grouped as metals or carbon. The Los Alamos 


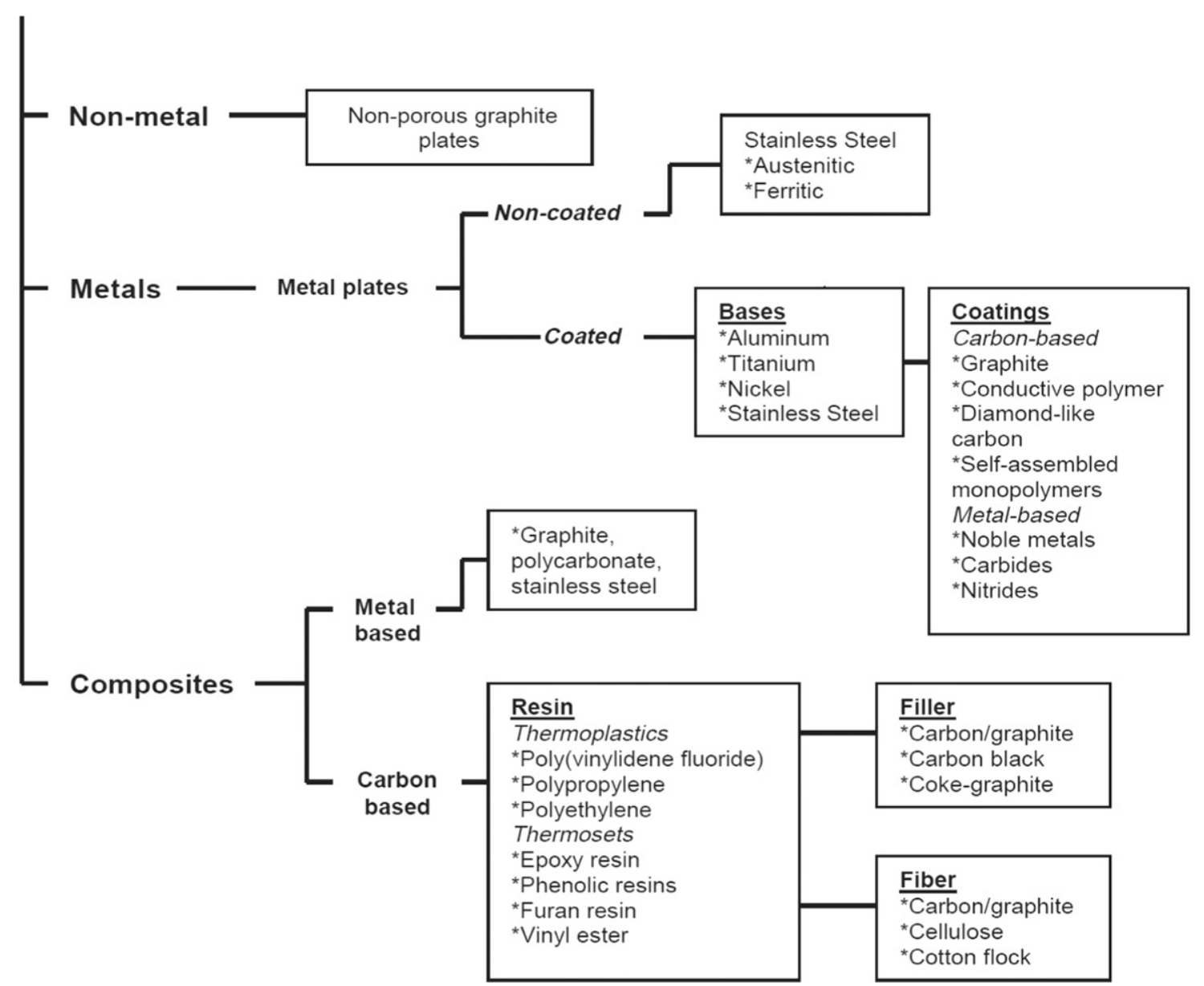

Fig. 2 Flow plate materials for fuel cell stack. Authorization to reproduce obtained from ref. Wilberforce, T., Al Makky, A., Baroutaji, A., Sambi, R., Olabi, A.G., 2017. Computational fluid dynamic simulation and modelling (CFX) of flow plate in PEM fuel cell using aluminum open pore cellular foam material. In: Proceedings of the Power and Energy Conference (TPEC), Texas: IEEE. doi:10.1109/TPEC.2017.7868285.

National Laboratory [35] conducted research on a metal based composite flow plate material and the material they developed was made from porous graphite, polycarbonate plastic and stainless steel. Manufacturing porous graphite plate does not require lot of time like that of non - porous graphite plates. It is also not expensive compared to the non - porous graphite plates. It is possible to produce the bipolar plate whiles the stainless steel and the polycarbonate part provide the impermeability. Stainless steel supports the structure and the possibility of corrosion is curbed using the graphite. Chemical resistance is provided by the polycarbonate and can be transformed into any specific shape to form the gasket as well as the manifold. The plate that was layered showed a better option in terms of stability and the price of the material. The possibility of using composite made of carbon as flow plate in cell stacks has also been investigated. The usage of thermoplastics or thermosetting is one method of producing carbon composite bipolar plates. There has been a major progress in using graphite - polymer composite materials as bipolar plates [43-46]. The manufacturing of materials that is very conductive but made of composite and having excellent properties as well as easily produced commercially for flow plates were all investigated [47]. Another researcher also concluded in his report that the long - term performances of carbon composite flow plates could be likened to graphite. Heinzel et al. [38] also reported that there is the possibility of developing a flow plate based on thermoplastics and carbon compounds. A vinyl ester graphite composite bipolar plate has also been developed by Kuan et al. [39] and this involves a bulk molding compound approach with characterisitcs same to graphite plates. Some companies like DuPont and ICM Plastics are well known for the sale of polymer - graphite composite flow plates [48-57]. It must also be noted that polymer composite material for bipolar plate usually comes as either a polymer or filler as reinforcing material. Fig. 3 shows an example of composite based flow plate material.

\subsection{Polymers}

Thermoplastic and thermoset can be used to manufacture bipolar plates [35]. The production of bipolar plates need large proportions of fillers irrespective of the nature of the polymer and this usually leads to wetting problems [43]. The polymer should be able to wet the fillers provided the distinction between the fillers and polymers in terms of their surface energies are negligible 


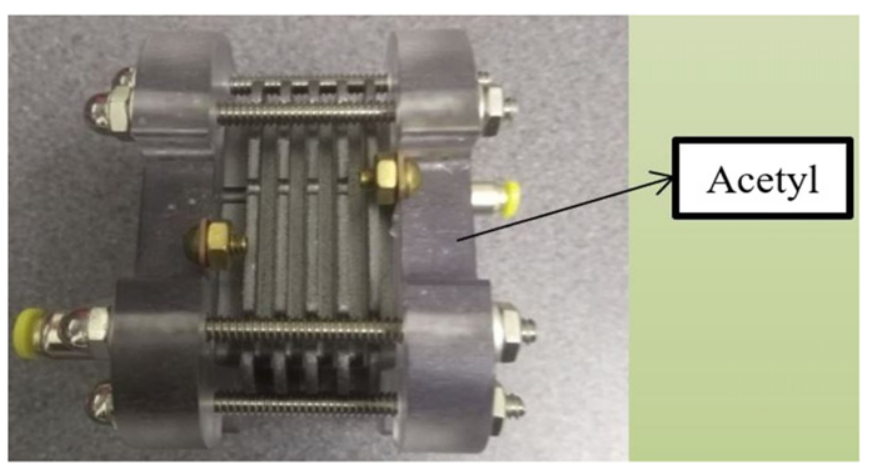

Fig. 3 PEMFC made of a composite/polymer bipolar plate. Authorization to reproduce obtained from ref. Wilberforce, T., El-Hassan, Z., Khatib, F.N., et al., 2017. Modelling and simulation of proton exchange membrane fuel cell with serpentine bipolar plate using MATLAB. International Journal of Hydrogen. doi:10.1016/j.ijhydene.2017.06.091.

as this will result in an increase in the concentration of the fillers. According to research performed by Dhakate et al. [44] polymers with polar groups helps the conductive path, therefore the flow of electricity in the polymer increases appreciably as well [44,46]. There are two types of polymers suitable for bipolar plates. These are thermoset and thermoplastic polymers [35,47].

\subsubsection{Thermosets}

Thermosettings have high strength compared to thermoplastics, ability to resist creep and low mechanical strength [46]. Thermosetting break easily compared to thermoplastics. At higher temperature conditions beyond $120^{\circ} \mathrm{C}$, thermosets can maintain their thermal and dimensional stability compared to thermoplastics. Curing process is usually initiated at higher temperatures than the glassing temperature but the viscosity of thermosets is lower at these conditions compared to thermoplastics. These characteristic properties of thermosets are some main reasons for their easy flow of electricity property, mechanically strong as well as reduced porosity of thermoset composites. Different investigations conducted recently is aimed at determining other alternative resins for composite bipolar plates. From literature, three types of thermosets have been thoroughly discussed. These are epoxy $[58,59]$, phenolic [60-64] and vinylester [46] resins. Some of the thermoset resins at room temperature are liquid example the vinylesters found in styrene [65-69]. Other resins must be dissolved in a solvent. Other reins come as either solids or liquids example Epoxy. They come as solid powder shape and even a hardener [69-71]. The last resin that is phenolic are classified into two, that is, resole and novalac [68]. A reaction of formaldehyde and excess amount of phenol with acid catalyst speeding up the chemical reaction leads to the production of novolac [69]. Resole on the other hand is formed by reacting phenol with excess amount of formaldehyde with a base serving as the catalyst. Another agent is need when using novalac resin to aid in curing reaction completely. Hexamethylene tetramine which has methylol group is the agent often used but there is no special agent needed for resole [69]. Polymers allow different processing methods to be applied on them because they come in different forms (Power or liquid). Liquid resins allow the addition of fillers in higher contents in the composite. Solvent is not needed when the resin is in the form of a powder and this makes molding it very difficult.

\subsubsection{Thermoplastics}

Research work being carried out in fuel cell using thermoplastics for the bipolar plates is also becoming another area of research [72-76]. These materials use fewer amount of fillers so they sometimes look unattractive and less competitive with the other types like the thermosets because they are highly viscous but a shorter cycle time and solvent free process can help mitigate this challenge. Polypropylene is the common and most acceptable type of thermoplastic used as bipolar plate [77-82]. Polypropylene is cheap [83], and it has excellent processing conditions as well as mechanical properties [84]. Another material considered for thermoplastics is polyvinylidene fluoride (PVDF) [80,81]. It does not allow easy penetration of other reactant gases, chemically not reactive, mechanically strong as well as able to resist moisture $[82,83]$. Other research on polyphenylene sulfide (PPS) has also been conducted because its mechanical properties are good and can be prepared using filler with high contents [84-89]. Polyethylene [87], polyether ether ketone [88], polyethylene terephthalate (PET), polyphenylene oxide [89], nylon [90] and liquid crystalline are some well-known thermoplastics used for bipolar plates [91]. During curing reactions, thermosets allow some gases to escape. Some of these gases are hydrogen, ammoniac and water vapor. The gas pores are usually preferred to be closed and that can only be achieved when the composite is kept under high pressure during its preparation and this also aid in the release of the gas being produced. Using differential scanning calorimetry (DSC) and Thermo-Gravimetry analysis (TGA) are means that can help in the easy specification of the time and temperature delay. There are no curing reactions for thermoplastics. The die where the thermoplastic composite is kept must be cooled below glassing temperature of polymer for thermoplastics to attain a stable state.

\subsubsection{Method of molding}

The slurry [92], Wet lay (WL) [93], solid state shear pulverization [94], hot compression (HC) [95-98] and the injection molding (IM) [99-101] are some common means of producing composite bipolar plates. Higher electrical and thermal conductivity is obtained when 
the hot compression molding method is applied. There is also good dimensional stability using this approach. In the injection molding method, it is impossible to keep the die at such high operating conditions (temperature) with the pressure also being constant, but the hot compression method allows the die to be maintained. In thermosets polymers, keeping a specific temperature and pressure is important to eliminate the gases released during curing hence reducing the porous nature of the composite. A major disadvantage of the IM method is the maximum filler composition added during formulation process is less. The rationale behind is because low viscosity is required to support the easy flow of the material. Conditions during the processing and the direction of the flow in the mold determines the physical characteristics of the composite material. The position of fillers precisely along the direction of the flow for the IM method is many compared to that of compression molding. Materials are sometimes wasted during injection molding especially in the single or double extruder die compared to the compression molding. Till date, the hot compression approach is the well-known strategy for the production of bipolar plates for thermoset composite bipolar plates.

\subsubsection{Fillers}

All polymers have the characteristics of an electrical insulator hence their ability to conduct electricity is achieved through the addition of conductive fillers. These fillers are sometimes metallic conductors or derivatives of carbons. A number of research in literature are centered around carbon fillers even though metallic conductors are also explored partially as well [101]. The combination of metals and a polymer has it's on challenges. The high density of metals coupled with their low corrosion resistance are two main issues that discourage the usage of metals in composite bipolar plates particular among the research community. The popular carbon fillers used for the manufacturing of flow plates are Graphite (G), Expanded Graphite (EG) and carbon fiber (CF) as show in Fig. 4.

\subsubsection{Non-porous graphite}

Graphite remains one of the most popular materials suitable for fuel cell flow plates. It comes either as natural or synthetic. This type of material has good chemical stability and performs well when used in a fuel cell. The resistivity of graphite is very low, making it yield high power after electrochemical reaction. it is quite expensive and its mechanical strength is also low. Flow channels must also be created on the flow plates and this is done by machining the channel design on the plates [103]. Scientists today are considering other alternatives to increase the physical as well as chemical characteristics of fuel cell by improving the material.

\subsubsection{Graphite}

The most common bipolar plate material as mentioned earlier is graphite [86]. Apart from diamond and fullerenes, graphite is often in crystalline form. It has good metallic characteristics like very excellent resistance to corrosion, good thermal and electrical conductivities and other properties like inertness and lubricity. Graphite is considered a type of filler that is micro sized with less specific surface as well as low aspect ratio of one. There is therefore an increase in the mechanical property of graphite. The layers of graphite have no reactive surface group and they are usually structure layers having c - axis lattice normally being $0.66 \mathrm{~nm}$. The morphology of graphite shown in Figs. 4(a) and (4b) captures the fracture surface of polymer composite. Graphite have higher electrical conductivity when compared to other existing types of fillers. They are made up of graphene layers interconnected via weak van der Waals forces shown in Fig. 5.

It implies flow of electricity through plane is smaller than that of in - plane for every graphite particle. The electrical conductivity of graphite is estimated to be $10^{4} \mathrm{~S} \mathrm{~cm}^{-1}$ at room temperature [87]. Again, it is highly corrosion resistant but challenging in machining flow channels on them as explained earlier and they are also very brittle hence reducing their suitability for the production of a BP [90]. To lower the brittleness for graphite used as flow plates, they are made to have big thickness which in effect increases the weight of the fuel cell as well as the volume [91]. They also have density of $2 \mathrm{~g} \mathrm{~cm}^{-3}$ which is very low.

\subsubsection{Expanded graphite (EG)}

Expandable graphite is obtained through the intercalation of natural graphite by means of modification using different chemical species. The expandable graphite is first introduced to heat in an oven (muffe) at over $800^{\circ} \mathrm{C}$ temperature to form the expanded graphite (EG) [90-95]. The usage of microwave irradiation in heating the EG is also being investigated lately because it is environmentally friendly and less expensive alternative compared with the traditional way of heating Expanded graphite. The EG is able to expand and exfoliate almost 200 times when introduced to microwave heat for only $30 \mathrm{~s}$ along the c-axis direction [96]. The morphology of pure expanded graphite shown in Figs. 4(c) and 4(d) depicts the fracture surface of expanded graphite composite. High expansion of expanded graphite causes alteration of the spacing within the layers of the graphite causing the density to reduce between $10^{-3}$ and $10^{-2} \mathrm{~g} \mathrm{~cm}^{-3}$ whiles the area as well as the aspect ratio will appreciably increase to $40 \mathrm{~m}^{2} \mathrm{~g}^{-1}$ and 15 respectively. Electrical characteristics tend to do well $\left(12,500 \mathrm{~S} \mathrm{~cm}^{-1}\right)$ according to an investigation made by some researchers [92]. Graphite nano platelets are created when the exfoliation is introduced to a solvent. Another investigation also reported that the graphite nanoplatelets are able to attain an electrical conductivity of almost $350 \mathrm{~S} \mathrm{~cm}^{-1}$ which is higher than the electrical properties for bipolar plate applications. The high electrical conductivity of expanded graphite has recently been considered as material suitable for bipolar plate and another factor for their suitability for bipolar plates has to do with their high aspect ratio [93-110]. The high aspect ratio reduces percolation threshold in composite bipolar plate [110,111]. This must however be noted that the mechanical strength tends to decrease whenever there is an increase in filler loading of composite bipolar plates hence it is imperative that an optimization of the filler loading must be carried out using a different filler example CF [110]. 

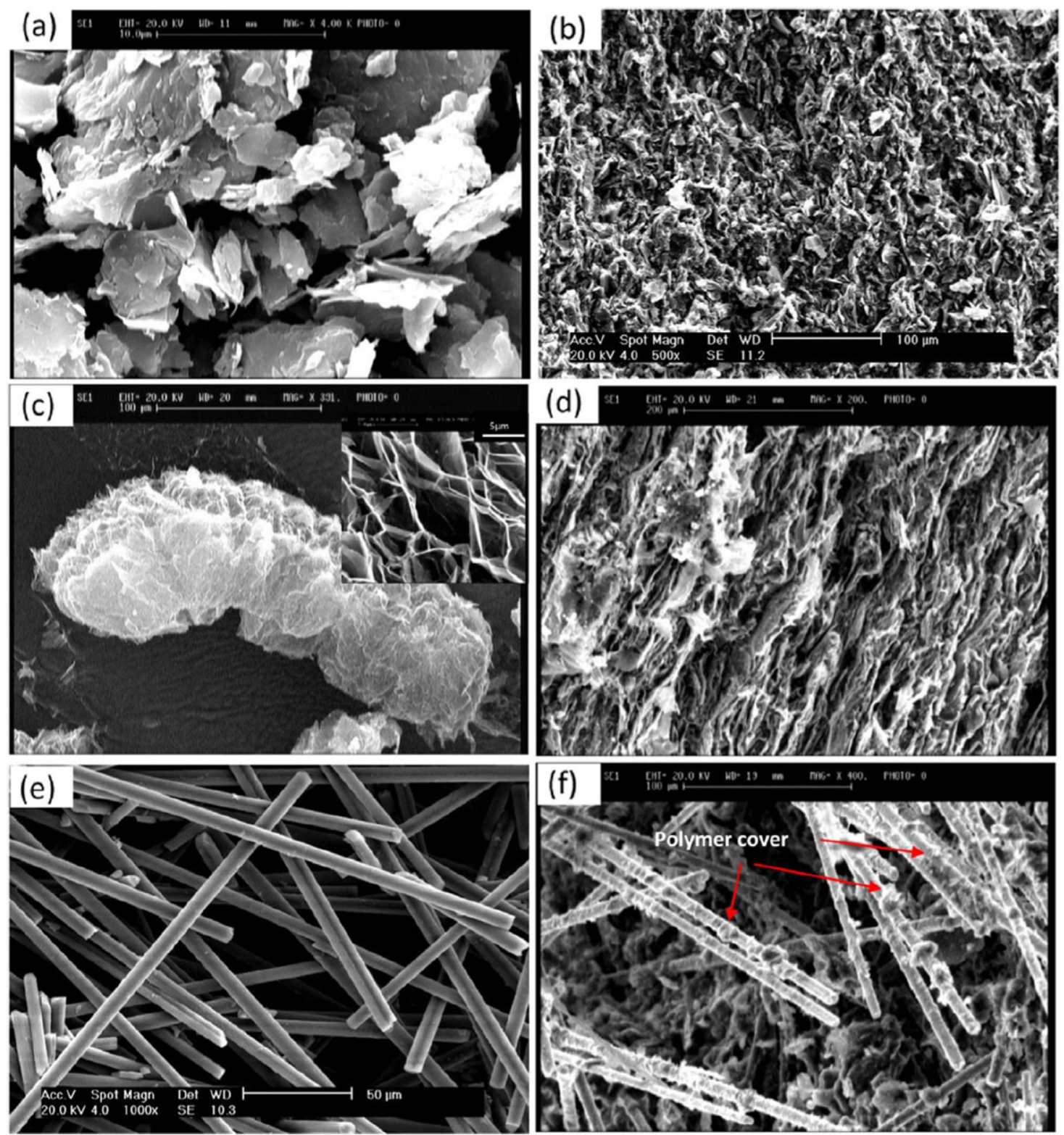

Fig. 4 SEM micrographs images for: (a) Graphite, (b) P/G composite, (c) expanded graphite, (d) P/EG composite, (e) carbon fiber, and (f) P/CF composite. Authorization to reproduce obtained from ref. Wilberforce, T., Alaswad, A., Palumbo, A., Olabi, A.G., 2016. Advances in stationary and portable fuel cell applications. International Journal of Hydrogen Energy 41 (37).

\subsubsection{Carbon fibers (CF)}

They are carbon materials but synthetic in nature as $90 \%$ of the material composition is being dominated by carbon. They are formed using various types of precursors such as rayon, pitch and polyacrylonitrile (PAN). The common precursor for the manufacture of high performance polyacrylonitrile carbon fibers is polyacrylonitrile. They are produced by means of pyrolysis of some specific polymeric fibers. The manufacturing process usually involves three stages that is, spinning, stabilization (oxidation) and carbonization. Polymerization of the polyacrylonitrile is the first stage. The material is spun after the polymerization to get the polyacrylonitrile fibers. These fibers are then thermally treated at low temperatures between two hundred and three hundred degrees Celsius but in an oxidative environment where cyclization, dehydrogenation and oxidation are the major reactive processes occurring. The structure of the polyacrylonitrile is changed chemically due to this process hence increasing their stability thermally, for them to maintain their shape and structure during carbonization. Thermoplastic polyacrylonitrile fibers is changed to non - plastic compound due to the stabilization and this is able to resist heat at higher temperatures $[111,112]$. The polyacrylonitrile fibers being stabilized is then transformed to carbon fibers by means of carbonization that requires heat. Only carbon is retained during this stage. All other elements are eliminated leading to the formation of a graphite like structure [112]. The next stage involves the heating of the carbon fibers under tension between temperatures of $2000-2500^{\circ} \mathrm{C}$ and $3000^{\circ} \mathrm{C}$. This process is 


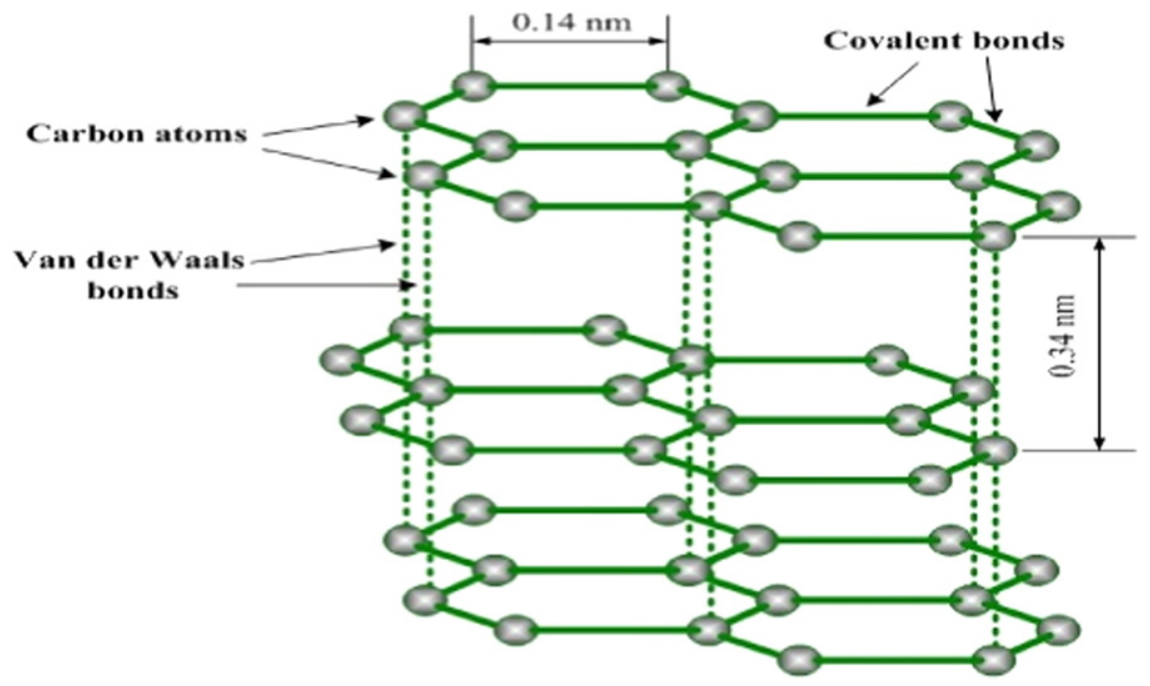

Fig. 5 Weak van der Waals forces showing graphene bonding forces in graphite. Authorization to reproduce obtained from ref. Wilberforce, T., Alaswad, A., Palumbo, A., Olabi, A.G., 2016. Advances in stationary and portable fuel cell applications. International Journal of Hydrogen Energy 41 (37).

carried out in order to graphitize the fibers. The last stage involves using poly matrix to enhance their adhesion by making the carbon fibers undergo surface heat treatments [112]. CF are utilized as composites using light weigh matrix. CF are fillers but they are micronized and again they have high aspect ratio which determines the strength and stiffness of a material hence making them a bit stronger than graphite even at lower intrinsic conductivity [36,37]. The morphology of pure carbon fibers filament is also shown in Fig. 4(e) and that of the fracture surface of carbon fiber composite can also be seen in Fig. 4(f). The strength of the flow plate mechanically tends to increase when carbon fibers are used and this in effect leads to further increment in the conductivity of the flow plate electrically [112-117]. Percolation threshold of the flow plate tends to decrease when the aspect ratio of the carbon fiber is less [117] but the porosity value increases when the aspect ratio increases as well, and this causes the hydrogen permeability to increase. An increase in the filler loading increases this anomaly. Augmenting the wettability of carbon fibers using polymer or a filler with loading of $30 \mathrm{wt} \%$ is the only solution to mitigate this challenge [110].

\subsubsection{Carbon black $(C B)$}

This is an elemental carbon produced synthetically. There are sometimes used as an additive for reinforced rubber products. The process leading to the production of carbon black involves 5 main stages. They are currently made using Furnace or acetylene processes [116]. A reactor is first preheated to a temperature of $800^{\circ} \mathrm{C}$ before the acetylene gas is introduced. There is an exothermic decomposition of the acetylene at this high reactor temperature. This leads to the production of carbon black surface with temperature exceeding $2500^{\circ} \mathrm{C}$ but in reality, the formation of carbon black is normally between 800 and $2000^{\circ} \mathrm{C}$. Acetylene black have intermediate particle size and also have its crystallinity being fairly high compared to other types of carbon blacks. They equally have high structure but show low reactivity. These characteristics of CB has made them good material selection option for applications that require good electrical and thermal conductivity. CB comes as pellets between 100 and $2 \mathrm{~mm}$ and when combined with a polymer, the pellets separates into primary agglomerates $30-100 \mathrm{~nm}$ long. This material aid in the improvement of the electrical conductivity even at lower filler loadings. The general nature of the carbon black having high surface area helps it to contact huge amount of polymer leading to the improvement of electrical conductivity even at lower concentration of the carbon black [118]. There is a clear difference between carbon black, graphite and carbon fibers even though they are all made of carbon. Carbon black is made up of aggregates having their configurations complex, quasi graphitic structure and colloidal dimensions $[118,119]$. The morphology of carbon black is complex. Using CB as bipolar plate material is highly possible but it's low mechanical strength and low electrical conductivity reduces its suitability for bipolar plate needed for commercial purposes [51].

\subsubsection{Carbon nanotubes (CNT)}

The carbon with tubular structure is called Carbon nanotubes. The structure of the tube is normally between 1 and $50 \mathrm{~nm}$ in diameter and $1 \mathrm{~mm}$ to very small centimeters in terms of length [119]. The aspect ratio of Carbon nanotubes is very large. Today carbon nanotubes are used mainly for multiwall or as single walls for laboratory purposes [120]. The research community is currently turning their attention to carbon nanotubes because their physical characteristics are unique. Carbon nanotubes have their elastic modulus being very large hence they are noted for reinforcing agents. Carbon nanotubes having small diameters exhibits semi - conducting or metallic characteristics but that is dependent on their molecular structure. Carbon nanotubes play a vital function in the catalyst layer for PEMFC, mainly as support sites for the platinum. Carbon nanotubes are generally expensive 
hence using them for bipolar plate will exceed the minimum expected cost of bipolar plates being less than $5 \$(\mathrm{k} \mathrm{W})^{-1}$. There is synergic effect using carbon nanotubes fillers due to their high aspect ratio but this can be curbed if the agglomeration of carbon nanotubes via the polymer is controlled properly. Other research was conducted using filler loading of 1 wt\% [121-123]. The possibility of improving the characteristics of composite bipolar plate by means of nano structure filler has also been investigated. This process requires using several vol\% of multi wall CNT in graphite - polymer composite bipolar plates. According to research, adding $1 \mathrm{vol} \%$ of multi wall carbon nano tubes increases the electrical as well as thermal conductivity for nano composite by nearly $100 \%$ [123]. The corrosion current density $\left(\mathrm{I}_{\text {corr }}\right)$ of material made of composite in varying carbon nano tubes weight percentages was less than the DOE standard of $1 \mu \mathrm{A} \mathrm{cm}^{-2}$. Formation of multi wall carbon nanotubes agglomerates can lead to depressing the resistance to corrosion as well as the electrical conductivity.

\subsubsection{Graphene}

At very low filler content graphene can still show some good characteristics hence their recent interest by the research community as a suitable material for bipolar plates. Other research has been done using graphene and graphene oxide. Graphene is also used during the manufacturing of nano composites with varying polymer matrices [123-130]. The percolation threshold is even achieved at low filler loading for most graphene-based polymer nano composites. A crystalline flake graphite is formed when several layers of graphene are stack together [124]. Graphene is very light $\left(1 \mathrm{~m}^{2}\right.$ sheet weighing $\left.0.77 \mathrm{mg}\right)$ and super conductive electrically. It is also very strong compared to other materials extraordinarily. The production cost of graphene is very high hence reducing their suitability for bipolar plate materials. Graphene was utilized as filler in the bipolar plate material composition according to an investigation carried out by some group of researchers [130]. Characteristics of graphene reinforced composite flow plate was able to meet all these demands hence in terms of conductivity and mechanical characteristics graphene is considered to be more advantageous to use as filler compared to other bipolar plate materials. The limitation of the usage of graphene has to do with the cost of the material.

\subsection{Characteristics of Composite BP}

Alternative to metal and graphite bipolar plate is the polymer or carbon composite BP. This is because it is cheap, easy to machine flow channels on them, resistant to corrosion and also light in terms of weight [131-136]. The various designs and the kind of material for PEMFC has been studied in detail [23]. They presented current development of bipolar plate using various techniques. Other researchers investigated on conductive thermoplastic blends for injection and compression molding of bipolar plate with the aid of carbon filled PP and PPS [54]. Their research was directed towards the study of the characteristics of BP to $60 \mathrm{wt} \%$. loading of the fillers (natural, graphite, conductive carbon and carbon fibers). Another researcher used liquid crystal polymer as binder. The group used Carbon black and Carbon Fibers as fillers for producing the composite bipolar plate. They concluded that the new composite had good mechanical strength and low hydrogen permeability when used as bipolar plate. The electrical conductivity they reported after their investigation was $5.6 \mathrm{~S} \mathrm{~cm}^{-1}$. The electrical properties of bipolar plate were also investigated to ascertain the impact of some processing factors on their performance [132-147].

The approach utilized was mixing process as well as solution blending. Their investigation also concluded that heating the samples at $100^{\circ} \mathrm{C}$ for some hours caused a variation in how conductive the samples were electrically but the conductivity they published was only 10 $\mathrm{S} \mathrm{cm}^{-1}$. A suggestion was also made in their report, where a third additional conducting component was recommended to give high flow of electricity for the composite bipolar plate. An optimization for the process conditions of compressing molding for PF resin and graphite composite was also investigated by another group of researchers [134,148-169]. Their work showed that the best conductivity as well as the bending strength of the BP they investigated was $142 \mathrm{~S} \mathrm{~cm}^{-1}$ and $61.6 \mathrm{MPa}$ respectively. They generated this result after $1 \mathrm{~h}$ from $15 \%$ resin content and compression molding at $24^{\circ} \mathrm{C}$. They also tried enhancing the mechanical strength of the composite through the usage of nanofillers of carbon nanotubes [170-185]. An increase of the mechanical strength from 50 to 60 MPa for the bipolar plate was achieved through reinforcement of the material with $3 \%$ carbon nanotube according to their research. The electrical conductivity tends to decrease as the mechanical strength increases due to the addition of an organic matrix to the carbon - based fillers. It therefore becomes necessary that the two properties are in perfect agreement with each other. Other research groups have also investigated the electric conductivity and strength of phenolic resin, carbon fibers, graphite and enhanced graphite composite [171-185]. They studied the impact of each filler on the various material through the addition of 10-80 wt\% of the filler. The synergic impact of two fillers was identified by fabricating double filler and triple filler composites according to their investigations. Their work also led to the development of a triple filler composite made of phenolic resin, $45 \mathrm{wt} \%$ of graphite, $10 \mathrm{wt} \%$ of enhanced graphite, $5 \mathrm{wt} \%$ of carbon fiber and thin carbon fiber cloth shown in Fig. 6.

The flexural strength for this composite from their investigation was $74 \mathrm{MPa}$, toughness, $39 \mathrm{~J} \mathrm{~m}^{-1}, 101 \mathrm{~S} \mathrm{~cm}^{-1}$ was the conductivity determined electrically, thermal conductivity greater than $9 \mathrm{~W}(\mathrm{~m} \mathrm{~K})^{-1}$ and porosity less than 5 vol\% using this composite yielded maximum power density of $810 \mathrm{~mW} \mathrm{~cm}^{-2}$. A formula that predicted the conductivity of composites made of polymer electrically was also proposed by another researcher [186].

\section{Metals}

Metals sheets are also being explored as alternative material for flow plates because metals have excellent mechanical strength, conduct electricity as heat very well and easy to shape to any design for the flow channels. Metal plates are susceptible to corrosion 


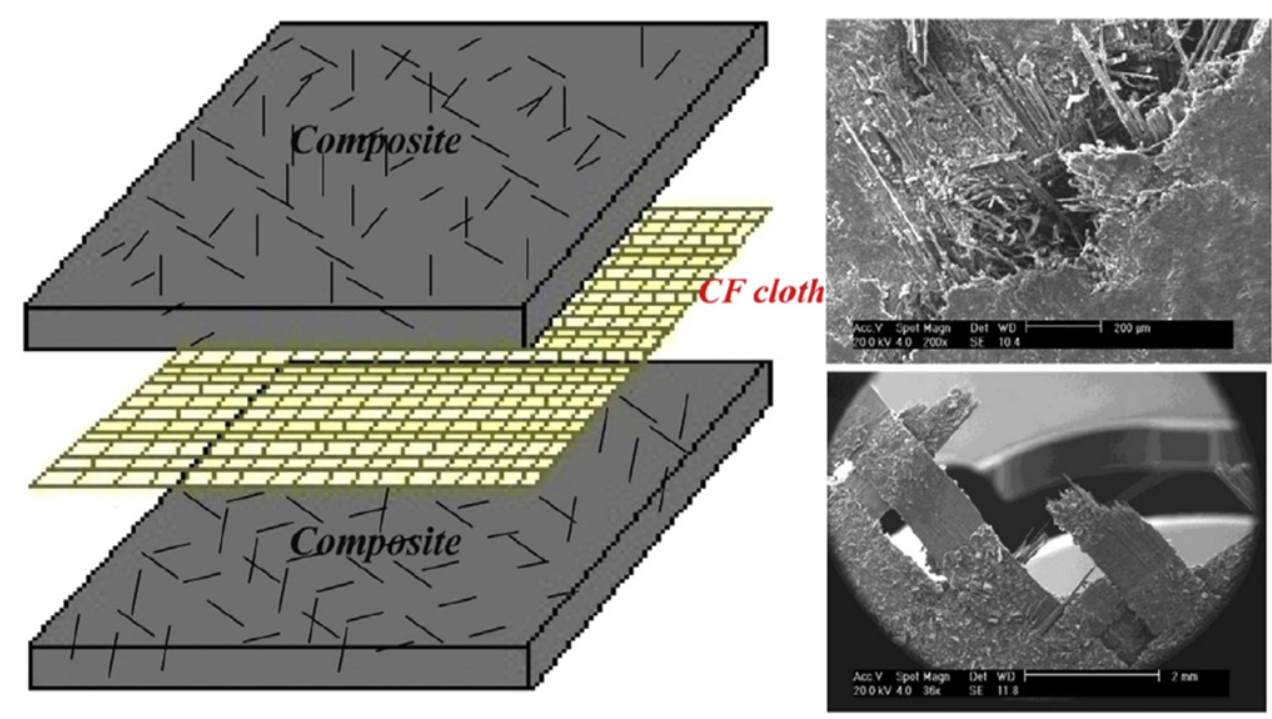

Fig. 6 Diagram showing a triple filler composite. Authorization to reproduce obtained from ref. Wilberforce, T., El-Hassan, Z., Khatib, F.N., et al., 2017. Developments of electric cars and fuel cell hydrogen electric cars. International Journal of Hydrogen 42 (40), 25695-25734. doi:10.1016/j. ijhydene.2017.07.054.

when exposed to a $\mathrm{pH}$ of $2-3$ and a temperature above $80^{\circ} \mathrm{C}$. The metal ions that is dissolved cause poisoning of the fuel cell membrane hence reducing ionic conductivity. The electrical resistance in the fuel cell increases when an area the flow plate becomes corroded and this reduces the performance of the fuel cell. This report reviewed 2 types of metallic plates that is coated and non - coated. These metals include aluminum, stainless steel, titanium and nickel. Their good conductivity with respect to electricity and heat, ability to go through plastic deformation without the material being destroyed, easy to manufacture, gas impermeability as well as mechanical strength makes them very attractive for flow plates. They are generally tough and can resist shocks compared to graphite and composite bipolar plates. They can also be easily fabricated making them advantageous compared to other materials. Metals equally has some well-known disadvantage like being easily corroded when exposed to hash atmospheric conditions [187]. Corrosion in PEM fuel cells usually happen at the anode and cathode region of the fuel cell. Reduction of the protective metal oxide layer occurs around the anode when exposed to harsh environmental conditions and this leads to hydride being formed and dissolution of the metal in water. Adding water vapor to the hydrogen to keep the membrane humidified is one medium where corrosion could occur in the fuel cell. This again can contaminate the fuel cell, limiting the operational characteristics of the catalytic surface and the fuel cell as a whole. The cathode is the region where the air is oxidized and this also tends to increase the rate of corrosion of the metal bipolar plate increasing the losses and sometimes malfunction of the entire fuel cell prematurely. Coating of the metals has also been investigated by several researchers to reduce the possibility of corrosion [33]. Stainless steel (SS), aluminum, nickel and copper are materials used in the manufacturing of flow plate [24]. Most research conducted is related to Fe - based alloys particularly SS because they are cheap and very abundant. Some metals like stainless steel and titanium are general stable when they are used in fuel cells because they have low $\mathrm{pH}$ due to passivation for good corrosion characteristics. Stainless steel and titanium have strong mechanical strength and the gas permeation rate is low [188-201]. Several investigations have been conducted using stainless steel and titanium because even in acidic conditions, titanium and stainless steel still maintain their properties.

\section{Conclusion}

The work investigated materials for the manufacturing of bipolar plates in cell stacks. Graphite and carbon continue to dominate materials for BP. The cost of fuel cell will reduce after a period of time as the cost of these materials keep reducing from time to time. It implies that bipolar plates are commercially becoming reliable which in effect will reduce the prices of PEM fuel cells as well as also increase their availability on the energy market but the electrical conductivity of graphite still remains a challenge. Middelman et al. [47] in their investigation concluded that the conductivity for graphite was nearly $20 \mathrm{~S} / \mathrm{cm}$ which was well below the target of being greater than $100 \mathrm{~S} / \mathrm{cm}$ acc. The entire conductivity for DuPonts bipolar plate is between 25 and $33 \mathrm{~S} / \mathrm{cm}$. Scientists today are working to produce bipolar plates which are consistent in terms of physical and chemical properties. The automobile industry is encouraging the use of metals as bipolar plates due to metals having small thickness and weight as well as good conductivity both thermally and electrically. Using stainless steel would reduce the cost but non - coated SS from investigation still have some challenge with surface - insulating layer. It therefore becomes imperative that it is coated using a thin coating of a chemically stable and electrically conducting film before it can be suitable for bipolar plates. Several researches is being conducted on coated metal plates and polymer - graphite composites. Despite the fact that there has been good progress made, 
researchers are yet to attain long - term reliability and power densities known to usually be the properties of non - porous graphite. It therefore implies that economics, manufacturability and long - term reliability determines the effect of the materials when used as flow plates for fuel cells hence the need for further investigation into this grey area.

\section{Reference}

[1] Wilberforce, T., Alaswad, A., Palumbo, A., Olabi, A.G., 2016. Advances in stationary and portable fuel cell applications. International Journal of Hydrogen Energy 41 (37),

[2] Wilberforce, T., Al Makky, A., Baroutaji, A., Sambi, R., Olabi, A.G., 2017. Computational fluid dynamic simulation and modelling (CFX) of flow plate in PEM fuel cell using aluminum open pore cellular foam material. In: Proceedings of the Power and Energy Conference (TPEC), Texas: IEEE. doi:10.1109/TPEC.2017.7868285.

[3] Ozen, D.N., Timurkutluk, B., Altinisik, K., 2016. Effects of operation temperature and reactant gas humidity levels on performance of PEM fuel cells. Renewable and Sustainable Energy Reviews 59, 1298-1306. doi:10.1016/j.rser.2016.01.040.

[4] Paul, B., Andrews, J., 2017. PEM unitised reversible/regenerative hydrogen fuel cell systems: State of the art and technical challenges. Renewable and Sustainable Energy Reviews 79, 585-599. doi:10.1016/j.rser.2017.05.112.

[5] Wang, Y., Leung, D.Y.C., Xuan, J., Wang, H., 2016. A review on unitized regenerative fuel cell technologies, part-A: Unitized regenerative proton exchange membrane fuel cells. Renewable and Sustainable Energy Reviews 65, 961-977.

[6] Wilberforce, T., El-Hassan, Z., Khatib, F.N., et al., 2017. Modelling and simulation of proton exchange membrane fuel cell with serpentine bipolar plate using MATLAB. International Journal of Hydrogen 42 (40), 25639-25662.. doi:10.1016/j.ijhydene.2017.06.091.

[7] Wilberforce, T., El-Hassan, Z., Khatib, F.N., et al., 2017. Developments of electric cars and fuel cell hydrogen electric cars. International Journal of Hydrogen 42 (40), 25695-25734. doi:10.1016/j.jijhydene.2017.07.054

[8] Wang, Y., Leung, D.Y.C., Xuan, J., Wang, H., 2017. A review on unitized regenerative fuel cell technologies, Part B: Unitized regenerative alkaline fuel cell, solid oxide fuel cell, and microfluidic fuel cell. Renewable and Sustainable Energy Reviews 75, 775-795.

[9] Mortazavi, M., Tajiri, K., 2015. Two-phase flow pressure drop in flow channels of proton exchange membrane fuel cells: Review of experimental approaches. Renewable and Sustainable Energy Reviews 45, 296-317.

[10] Farooqui, U.R., Ahmad, A.L., Hamid, N.A., 2018. Graphene oxide: A promising membrane material for fuel cells. Renewable and Sustainable Energy Reviews 82. 714-733. Part 1.

[11] Priya, K., Sathishkumar, K., Rajasekar, N., 2018. A comprehensive review on parameter estimation techniques for Proton Exchange Membrane fuel cell modelling. Renewable and Sustainable Energy Reviews 93, 121-144.

[12] Wilberforce, T., Al Makky, A., Baroutaji A., Sambi R., Olabi A.G., 2017. Optimization of bipolar plate through computational fluid dynamics simulation and modelling using nickle open pore cellular foam material. In: Proceedings of the International Conference on Renewable Energies and Power Quality (ICREPQ'17), no 15. ISSN 2171-038X.

[13] Wilberforce, T., Alaswad, A., Mooney, J., Olabi, A.G., 2015. Hydrogen production for solar energy storage. A proposed design investigation. In: Proceedings of the 8th International Conference on Sustainable Energy and Environmental Protection. ISBN: 978-1-903978-52-8.

[14] Sengodan, S., Lan, R., Humphreys, J., et al., 2018. Advances in reforming and partial oxidation of hydrocarbons for hydrogen production and fuel cell applications. Renewable and Sustainable Energy Reviews 82, 761-780. Part 1.

[15] Shaari, N., Kamarudin, S.K., 2017. Graphene in electrocatalyst and proton conducting membrane in fuel cell applications: An overview. Renewable and Sustainable Energy Reviews 69, 862-870

[16] Majla, E.H., Rohendi, D., Daud, W.R.W., Husaini, T., Haque, M.A., 2018. Electrode for proton exchange membrane fuel cells: A review. Renewable and Sustainable Energy Reviews 89, 117-134.

[17] Wilberforce, T., Khatib, F.N., Al Makky, A., Baroutaji, A., Olabi, A.G., 2017. Characterization of Proton Exchange Membrane fuel cell through design of experiment (doe). In: Proceedings of SEEP2017, pp. 27-30. Bled, Slovenia.

[18] Umberto, L., 2014. Overview on fuel cells. Renewable and Sustainable Energy Reviews 30, 164-169.

[19] Wilberforce, T., Khatib, F.N., Emmanuel, et al., 2017. Experimental study of operational parameters on the performance of pemfcs in dead end mode. In: Proceedings of SEEP2017, pp. 27-30. Bled, Slovenia.

[20] Ahmad Zakil, F., Kamarudin, S.K., Basri, S., 2016. Modified Nafion membranes for direct alcohol fuel cells: An overview. Renewable and Sustainable Energy Reviews 65, $841-852$.

[21] Raza, R., Akram, N., Javed, M.S., et al., 2016. Fuel cell technology for sustainable development in Pakistan - An over-view. Renewable and Sustainable Energy Reviews $53,450-461$

[22] Andújar, J.M., Segura, F., Isorna, F., Calderón, A.J., 2018. Research Group TEP-192. Comprehensive diagnosis methodology for faults detection and identification, and performance improvement of air-cooled polymer electrolyte fuel cells. Renewable and Sustainable Energy Reviews 88, 193-207.

[23] Tian, R., 2011. Chromium nitride/Cr coated 316L stainless steel as bipolar plate for proton exchange membrane fuel cell. Journal of Power Sources 196 (3), 1258-1263. doi:10.1016/j.jpowsour.2010.08.028.

[24] Gago, A., Ansar, A., Wagner, N., Arnold, J., Friedrich, K.A., 2013. Titanium coatings deposited by thermal spraying for bipolar plates of PEM electrolysers. In: 4th European PEFC and H2 forum 2-5 July 2013. Lucerne, Switzerland.

[25] Pawlowski, L., 2008. The Science and Engineering of Thermal Spray Coatings. John Wiley \& Sons. doi:10.1002/9780470754085.ch8.

[26] Xia, L.-G., Li, A.-J., Wang, W.-Q., et al., 2008. Effects of resin content and preparing conditions on the properties of polyphenylene sulfide resin/graphite composite for bipolar plate. Journal of Power Sources 178 (1), 363-367. doi:10.1016/i.jpowsour.2007.11.094.

[27] Tian, R., 2011. Chromium nitride/Cr coated 316L stainless steel as bipolar plate for proton exchange membrane fuel cell. Journal of Power Sources 196 (3), 1258-1263. doi:10.1016/j.jpowsour.2010.08.028.

[28] Tibbetts, G.G., Lake, M.L., Strong, K.L., Rice, B.P., 2007. A review of the fabrication and properties of vapor-grown carbon nanofiber/polymer composites. Composites Science and Technology 67 (7-8), 1709-1718. doi:10.1016/j.compscitech.2006.06.015.

[29] Tsai, M.-Y., Hsu, C.-C., Chen, P.-H., Lin, C.-S., Chen, A., 2011. Surface modification on a glass surface with a combination technique of sol-gel and air brushing processes. Applied Surface Science 257 (20), 8640-8646. doi:10.1016/j.apsusc.2011.05.041.

[30] Sengupta, R., Bhattacharya, M., Bandyopadhyay, S., Bhowmick, A.K., 2011. A review on the mechanical properties of graphite and modified graphite reinforced polymer composites. Progress in Polymer Science 36 (5), 638-670.

[31] La Notte, L., Salamandra, L., Zampetti, A., et al., 2012. Airbrush spray coating of amorphous titanium dioxide for inverted polymer solar cells. International Journal of Photoenergy 2012. doi:10.1155/2012/897595.

[32] Antonucci, P., Romeo, F., Minutoli, M., Alderucci, E., Giordano, N., 1988. Electrochemical corrosion behavior of carbon black in phosphoric acid. Carbon 26 (2), 197-203. doi:10.1016/0008-6223(88)90037-1.

[33] Borup, R.L., Vanderborgh, N.E., 1995. Design and Testing criteria for bipolar plate materials for PEM fuel cell applications. Materials Research Society Symposia Proceedings $393,151-155$. 
[34] Cooper, J.S., 2004. Design analysis of PEMFC bipolar plates considering stack manufacturing and environment impact. Journal of Power Sources 129, 152-169. doi:10.1016/j.jpowsour.2003.11.037.

[35] Herman, A., Chaudhuri, T., Spagnol, P., 2005. Bipolar plates for PEM fuel cells, a review. International Journal of Hydrogen Energy 30, 1297-1302.

[36] Chunhui, S., Mu, P., Qin, Y., Runzhang, Y., 2006. Studies on preparation and performance of sodium silicate/graphite conductive composites. Journal of Composite Materials 40 (9), 839-848. doi:10.1177/0021998306061296.

[37] Sheppard, R.G., Mathes, D.M., Bray, D.J., 2001. Properties and Characteristics of Graphite for Industrial Applications. Poco Graphite. pp. 5-7.

[38] Ma, L., Warthesen, S., Shores, D., 2000. Evaluation of materials for bipolar plates in PEMFCs. Journal of New Materials for Electrochemical Systems 3 (3), $221-228$.

[39] Kitta, S., Uchida, H., Watanabe, M., 2007. Metal separators coated with carbon/resin composite layers for PEFCs. Electrochimica Acta 53 (4), $2025-2033$.

[40] Cunningham, B.D., Huang, J., Baird, D.G., 2007. Review of materials and processing methods used in the production of bipolar plates for fuel cells. International Materials Reviews 52 (1), 1-13. doi:10.1179/174328006X102556.

[41] Al-Saleh, M.H., Sundararaj, U., 2011. Review of the mechanical properties of carbon nanofiber/polymer Composites. Composites Part A Applied Science and Manufacturing 42 (12), 2126-2142. doi:10.1016/i.compositesa.2011.08.005.

[42] Wang, H., Turner, J.A., 2010. Reviewing metallic PEMFC Bipolar plates. Fuel Cells 10 (4), 510-519. doi:10.1002/fuce.200900187.

[43] Flandin, L., Chang, A., Nazarenko, S., Hiltner, A., Baer, E., 2000. Effect of strain on the properties of an ethylene-octene elastomer with conductive carbon fillers. Journal of Applied Polymer Science 76, 894-905. https://doi.org/10.1002/(SICI)1097-4628(20000509)76:6<894::AID-A>3.0.C0;2-K.

[44] Dhakate, S.R., Sharma, S., Borah, M., Mathur, R.B., Dham, T.L., 2008. Expanded graphite-based electrically conductive composites as bipolar plate for PEM fuel cell. International Journal of Hydrogen Energy 33 (23), 7146-7152. doi:10.1016/j.ijhydene.2008.09.004.

[45] Planes, E., Flandin, L., Alberola, N., 2012. Polymer composites bipolar plates for PEMFCs. Energy Procedia 20, 311-323.

[46] Taherian, R., 2012. Manufacture, test, modeling of polymer-based nanocomposite utilized in bipolar plate of PEM fuel cell. In: Material Engineering, Shiraz University, p. 246.

[47] Middelman, E., Kout, W., Vogelaar, B., Lenssen, J., de Waal, E., 2003. Bipolar plates for PEM fuel cells. Journal of Power Sources 118 (1-2), 44-46. doi:10.1016/ S0378-7753(03)00070-3.

[48] Lin, K., Li, X., Tian, L., Dong, H., 2015. Active screen plasma surface co-alloying of 316 austenitic stainless steel with both nitrogen and niobium for the application of bipolar plates in proton exchange membrane fuel cells. International Journal of Hydrogen Energy 40, 10281-10292.

[49] Lawrence, R., 1980. Low cost bipolar current collector-separator for electrochemical cells. US Patent 4214969 . (29 July).

[50] Balko, E., Lawrence, R., 1982. Carbon fibre reinforced fluorocarbon - graphite bipolar current collector separator. US Patent 4339322.

[51] Ledjeff-Hey, K., Mahlendorf, F., Neimzig, O., Trutmann, A., Mercator, G., 1988. In: Proceedings of the Fuel Cell, p. 570.

[52] Melchers, R.E., 2005. The effect of corrosion on the structural reliability of steel offshore structures. Corrosion Science 47, 2391-2410.

[53] Emanuelson, R., Luoma, W., Taylor, W., 1981. Separator plate for electrochemical cells. US Patent 4301222.

[54] Taylor, W., 1986. Coke and graphite filled separator plate for electrochemical cells. US Patent 4592968.

[55] Stewart, Jr., Robert, C., 1987. Carbon graphite component in an electrochemical cell and method for making the component. US Patent 4670300.

[56] Umera, T., Murakami, S., 1988. Method for producing carbon sheet and a fuel cell separator. US Patent 4737421.

[57] Besmann, T.M., Klett, J.W., Burchell, T.D., 1998. In materials for electrochemical energy storage and conversion II - Batteries, capacitors and fuel cells. In: Ginley, D.S., Doughty, D.H., Scrosati, B., Takamura, T., Zhang, Z. (Eds.) Proceedings of the Mater. Res. Soc. Symp. Proc. 496, pp. 243-248. Pittsburgh, PA.

[58] Hui, C., Hong-bo, L., Li, Y., Jian-xin, L., Yang, L., 2010. Study on the preparation and properties of novolac epoxy/graphite composite bipolar plate for PEMFC. International Journal of Hydrogen Energy 35 (7), 3105-3109. doi:10.1016/j.ijhydene.2009.08.030.

[59] Lee, H.S., Kim, H.J., Kim, S.G., Ahn, S.H., 2007. Evaluation of graphite composite bipolar plate for PEM (proton exchange membrane) fuel cell: Electrical, mechanical, and molding properties. Journal of Materials Processing Technology 187-188, 425-428. doi:10.1016/j.jmatprotec.2006.11.213.

[60] Heo, S.I., Oh, K.S., Yun, J.C., et al., 2007. Development of preform moulding technique using expanded graphite for proton exchange membrane fuel cell bipolar plates. Journal of Power Sources 171 (2), 396-403. doi:10.1016/j.jpowsour.2007.05.110.

[61] Mathur, R.B., Dhakate, S.R., Gupta, D.K., Dhami, T.L., Aggarwal, R.K., 2008. Effect of different carbon fillers on the properties of graphite composite bipolar plate. Journal of Materials Processing Technology 203 (1-3), 184-192. doi:10.1016/j.jmatprotec.2007.10.044.

[62] Besmann, T.M., Klett, J.W., Henry, J.J., Lara-Curzio, E., 2000. Carbon/carbon composite bipolar plate for proton exchange membrane fuel cells. Journal of the Electrochemical Society 147 (11), 4083-4086.

[63] Kakati, B.K., Sathiyamoorthy, D., Verma, A., 2010. Electrochemical and mechanical behavior of carbon composite bipolar plate for fuel cell. International Journal of Hydrogen Energy 35 (9), 4185-4194. doi:10.1016/j.jijhydene.2010.02.033.

[64] Dhakate, R., Mathur, R.B., Kakati, B.K., Dhami, T.L., 2007. Properties of graphite-composite bipolar plate prepared by compression molding technique for PEM fuel cell. International Journal of Hydrogen Energy 32 (17), 4537-4543. doi:10.1016/j.jijhydene.2007.02.017.

[65] Yen, C.-Y., Liao, S.-H., Lin, Y.-F., et al., 2006. Preparation and properties of high performance nanocomposite bipolar plate for fuel cell. Journal of Power Sources 162 (1), 309-315. doi:10.1016/j.jpowsour.2006.06.076.

[66] Raza, M.A., Ahmed, R., Saleem, A., Din, R.U., 2009. Fabrication of carbon-polymer composite bipolar plates for polymer electrolyte membrane fuel cells by compression moulding. Nucleus 46 (3), 351-356.

[67] Liao, S.-H., Hsiao, M.-C., Yen, C.-Y., et al., 2010. Novel functionalized carbon nanotubes as cross-links reinforced vinyl ester/nanocomposite bipolar plates for polymer electrolyte membrane fuel cells. Journal of Power Sources 195 (23), 7808-7817. doi:10.1016/j.jpowsour.2009.10.020.

[68] Kakati, B.K., Deka, D., 2007. Effect of resin matrix precursor on the properties of graphite composite bipolar plate for PEM fuel cell. Energy Fuels 21 (3), $1681-1687$. do: 10.1021/ef0603582.

[69] Liao, S.-H., Yen, C.-Y., Weng, C.-C., et al., 2008. Preparation and properties of carbon nanotube/polypropylene nanocomposite bipolar plates for polymer electrolyte membrane fuel cells. Journal of Power Sources 185 (2), 1225-1232. doi:10.1016/j.jpowsour.2008.06.097.

[70] Lee, J.H., Jang, Y.K., Hong, C.E., et al., 2009. Effect of carbon fillers on properties of polymer composite bipolar plates of fuel cells. Journal of Power Sources 193 (2), 523-529. doi:10.1016/j.jpowsour.2009.04.029.

[71] Ratna, D., 2009. Handbook of Thermoset Resins. iSmithers. (ISBN-10: 1847354106, ISBN-13: 978-1847354105).

[72] Wang, Y., 2006. Conductive thermoplastic composite blends for flow field plates for use in polymer electrolyte membrane fuel cells (PEMFC). In: Chemical Engineering. Waterloo.

[73] Mighri, F., Huneault, M.A., Champagne, M.F., 2004. Electrically conductive thermoplastic blends for injection and compression molding of bipolar plates in the fuel cell application. Polymer Engineering \& Science 44 (9), 1755-1765.

[74] Yeetsorn, R., Fowler, M., Tzoganakis, C., Yuhua, W., Taylor, M., 2008. Polypropylene composites for polymer electrolyte membrane fuel cell bipolar plates. Macromolecular Symposia 264 (1), 34-43.

[75] Handleya, C., Brandon, N.P., Vorst, R.V.D., 2002. Impact of the European Union vehicle waste directive on end-of-life options for polymer electrolyte fuel cells. Journal of Power Sources 106 (1-2), 344-352. doi:10.1016/S0378-7753(01)01019-9.

[76] Dweiri, R., Sahari, J., 2007. Electrical properties of carbon-based polypropylene composites for bipolar plates in polymer electrolyte membrane fuel cell (PEMFC). Journal of Power Sources 171 (2), 424-432. doi:10.1016/j.jpowsour.2007.05.106.

[77] Yuan, X.Z., Wang, H.J., Zhang, J.J., Wilkinson, D.P., 2005. Bipolar plates for PEM fuel cells - From materials to processing. Journal of New Materials for Electrochemical Systems 8, 257-267. 
[78] Chunhui, S., Mu, P., Runzhang, Y., 2008. The effect of particle size gradation of conductive fillers on the conductivity and the flexural strength of composite bipolar plate. International Journal of Hydrogen Energy 33 (3), 1035-1039.

[79] Del Rio, C., Ojeda, M.C., Acosta, J.L., et al., 2002. New polymer bipolar plates for polymer electrolyte membrane fuel cells: Synthesis and characterization. Journal of Applied Polymer Science 83 (13), 2817-2822.

[80] Arai, T., Tominaga, Y., Asai, S., Sumita, M., 2005. Study on correlation between physical properties and interfacial characteristics in highly loaded graphite-polymer composites. Journal of Polymer Science Part B Polymer Physics 43 (18), 2568-2577.

[81] Wu, M., Shaw, L.L., 2004. On the improved properties of injection-molded, carbon nanotube-filled PET/PVDF blends. Journal of Power Sources 136 (1), $37-44$. doi:10.1016/j.jpowsour.2004.04.016.

[82] Kongstein, 0.E., CEA NG, Ødegard, A. 2010. NEXPEL Project» Next generation PEM electrolyzer for sustainable hydrogen production WP5 "Porous current collectors and materials for bipolar plate". [Bibliographic review].

[83] Chen, S.H., Chien, R.D., Lee, P.H., Huang, J.S., 2005. Effects of molding conditions on the electromagnetic interference performance of conductive ABS parts. Journal of Applied Polymer Science 33 (3), 1072-1080. doi:10.1002/app.22241.

[84] Cunningham, B., Baird, D.-G., Mater, J., 2006. The development of economical bipolar plates for fuel cells. Chem 16, 4385-4388. doi:10.1039/B611883F.

[85] Cunningham, B.D., Baird, D.G., 2007. Development of bipolar plates for fuel cells from graphite filled wet-lay material and a compatible thermoplastic laminate skin layer. Journal of Power Sources 168 (2), 418-425. doi:10.1016/i.jpowsour.2007.03.036.

[86] Fujii, H., Maeda, T., 2014. Titanium alloys developed by Nippon steel \& Sumitomo metal corporation. Nippon Steel \& Sumitomo Metal Technical Report 106, pp. 16-21.

[87] Marais, C., Feillard, P., 1992. Manufacturing and mechanical characterization of unidirectional polyethylene-fiber/polyethylene matrix composites. Composites Science and Technology 45, 247-255.

[88] Wang, A., Lin, R., Polineni, V.K., et al., 1998. Carbon fibre reinforced polyether ether ketone composite as a bearing surface for total hip replacement. Tribology International 31, 661-667.

[89] Hauser, R.A., 2008. Synergistic Effects and Modeling of Thermally Conductive Resins for Fuel Cell Bipolar Plate Applications. Michigan: Chemical Engineering, Michigan Technological University.

[90] Kuo, J.-K., Chen, C.-K., 2006. A novel Nylon-6-S316L fiber compound material for injection molded PEM fuel cell bipolar plates. Journal of Power Sources 162 (1), 207-214. doi:10.1016/j.jpowsour.2006.06.034.

[91] Wolf, H., Porada, M.W., 2006. Electrically conductive LCP-carbon composite with low carbon content for bipolar plate application in polymer electrolyte membrane fuel cell. Journal of Power Sources 153 (1), 41-46. doi:10.1016/j.jpowsour.2005.03.182.

[92] Taylor, J.M., 2006. Thermoplastic composites for polymer electrolyte membrane fuel cell bipolar plates, In: Chemical Engineering. Waterloo.

[93] Meyyappan, M., 2004. In: Raton, B. (Ed.), Carbon Nanotubes Science and Applications. London: CRC Press. (ISBN 9780849321115 - CAT\# 2111).

[94] Abanilla, M.A., Li, Y., Karbhari, V.M., 2006. Durability characterization of wet layup graphite/epoxy composites used in external strengthening. Composites Part B Engineering 37 (2-3), 200-212. doi:10.1016/j.compositesb.2005.05.016.

[95] Taherian, R., Golikand, A.N., Hadianfard, M.J., 2011. The effect of mold pressing pressure and composition on properties of nanocomposite bipolar plate for proton exchange membrane fuel cell. Journal of Material \& design 32, 3883-3892.

[96] Taherian R., et al., 2011. The effect of ohmic resistances and clamping pressure on the performance of proton exchange membrane fuel cell. In: Proceedings of the 7th International Chemical Engineering Congress and Exhibition. Kish, Iran.

[97] Taherian, R., Hadianfard, M.J., Golikand, A.N., 2013. Manufacture of a polymer-based carbon nanocomposite as bipolar plate of proton exchange membrane fuel cells. Materials and Design 49, 242-251.

[98] Taherian, R., Hadinfard, M.J., Nozad, A., 2012. Manufacture Polymer Based Nanocomposite Bipolar Plate of PEM Fuel Cell. Office, I.R. (Ed.), Iran: Invention Establish Office of Iran, Shiraz University.

[99] Wilkinson, D.P., Zhang, J., Hui, R., Fergus, J., Li, X., 2011. Proton exchange membrane fuel cells: Materials properties and performance. Platinum Metals Review 55 (4), 225-228. doi:10.1595/147106711X595102.

[100] Kuo, J.K., Mi Chang, S., 2008. Compound Material for Injection Molded PEM Fuel Cell Bipolar Plates, ICSET.

[101] Tawfik, H., Hung, Y., Mahajan, D., 2007. Metal bipolar plates for PEM fuel cell - A review. Journal of Power Sources 163 (2), 755-767. doi:10.1016/j. jpowsour.2006.09.088.

[102] Taherian, R., Moradzaman, M., Hadianfard, M.J., Golikand, A.N., 2011. The optimization of ball milling method in preparation of phenolic/functionalized multi-wall carbon nanotube composite and comparison with wet method. International Journal of Engineering Research in Africa 5, 16-29.

[103] Hashmi, S.A.R., Dwivedi, U.K., Chand, N., 2007. Graphite modified cotton fiber reinforced polyester composites under sliding wear conditions. Wear 262 (11-12), $1426-1432$.

[104] Salwan, S., Dihrab, K., Sopian, M.A., Alghoul, M.A., Sulaiman, M.Y., 2009. Review of the membrane and bipolar plates materials for conventional and unitized regenerative fuel cells. Renewable and Sustainable Energy Reviews 13 (6-7), 1663-1668. doi:10.1016/..rser.2008.09.029.

[105] Kamarudin, S.K., Daud, W.R.W., Md. Som, A., Takriff, M.S., Mohammad, A.W., 2006. Technical design and economic evaluation of a PEM fuel cell system. Journal of Power Sources 157 (2), 641-649. doi:10.1016/j.jpowsour.2005.10.053.

[106] Larminie, J., Dicks, A., 2003. Fuel Cell Systems Explained, second ed. England The Atrium, Southern Gate, Chichester, West Sussex P019 8SQ: John Wiley \& Sons.

[107] Makkus, R.C., Janssen, A.H.H., de Bruijn, F.A., Mallant, R.K.A.M., 2000. Stainless steel for cost-competitive bipolar plates in PEMFCs. Fuel Cells Bulletin 3 (17), 5-9. doi:10.1016/S1464-2859(00)87319-8.

[108] Celzard, A., Mareche, J.F., Furdin, G., Puricelli, S., 2000. Electrical conductivity of anisotropic expanded graphite-based monolith. Journal of Physics D Applied Physics 33 (2000), 3094-3101

[109] Chen, M., Shen, X.J.W., Huang, W.Y., 2002. Novel electrical conductive polypropylene/graphite nanocomposites. Journal of Materials Science Letters 21 (3), $213-214$.

[110] Chen, G.-H., Wu, D.-J., Weng, W.-G., Yan, W.-L., 2001. Preparation of polymer/graphite conducting nanocomposite by intercalation polymerization. Available at: https:// doi.org/10.1002/app.2101.

[111] Song, L.N., Xiao., M., Li, X.H., Meng, Y.Z., 2005. Short carbon fiber reinforced electrically conductive aromatic polydisulfide/expanded graphite nanocomposites. Materials Chemistry and Physics 93 (1), 122-128. doi:10.1016/i.matchemphys.2005.02.033.

[112] Chen, H., Müller, M.B., Gilmore, K.J., Wallace, G.G., Li, D., 2008. Mechanically strong, electrically conductive, and biocompatible graphene paper. Advanced Material Science 20 (18), 3557-3561. doi:10.1002/adma.200800757.

[113] Yan, X., Hou, M., Zhang, H., et al., 2006. Performance of PEMFC stack using expanded graphite bipolar plates. Journal of Power Sources 160 (1), $252-257$. doi:10.1016/i.jpowsour.2006.01.022.

[114] Zheng, W., Wong, S.-C., 2003. Electrical conductivity and dielectric properties of PMMA/expanded graphite composites. Composites Science and Technology 63 (2), 225-235. doi:10.1016/S0266-3538(02)00201-4.

[115] Park, J.K., Do, I.-H., Askeland, P., Drzal, L.T., 2008. Electrodeposition of exfoliated graphite nanoplatelets onto carbon fibers and properties of their epoxy composites. Composites Science and Technology 68 (7-8), 1734-1741. doi:10.1016/j.compscitech.2008.02.002.

[116] Zheng, G., Wu, J., Wang, W., Pan, C., 2004. Characterizations of expanded graphite/polymer composites prepared by in situ polymerization. Carbon 42 (14), 2839-2847. doi:10.1016/j.carbon.2004.06.029.

[117] Zhao, Y.F., Xiao, M., Wang, S.J., Ge, X.C., Meng, Y.Z., 2007. Preparation and properties of electrically conductive PPS/expanded graphite nanocomposites. Composites Science and Technology 67 (11-12), 2528-2534. doi:10.1016/j.compscitech.2006.12.009. 
[118] Li, D., Wang, Y., Xu, L., Wu, J.L.Q., 2008. Surface modification of a natural graphite/phenol formaldehyde composite plate with expanded graphite. Journal of Power Sources 183 (2), 571-575. doi:10.1016/j.jpowsour.2008.05.071.

[119] Chen., W., Liu, Y., Xin, Q., 2010. Evaluation of a compression molded composite bipolar plate for direct methanol fuel cell. International Journal of Hydrogen Energy 35 (8), 3783-3788. doi:10.1016/j.ijhydene.2010.02.004.

[120] Song, L.N., Xiao, M., Meng, Y.Z., 2006. Electrically conductive nanocomposites of aromatic polydisulfide/expanded graphite. Composites Science and Technology 66, 2156-2162. doi:10.1016/i.compscitech.2005.12.013.

[121] Yasmin, A., Luo, J.-J., Daniel, I.M., 2006. Processing of expanded graphite reinforced polymer nanocomposites. Composites Science and Technology 66, 1179-1186.

[122] Antunes, R.A., de Oliveira, M.C.L., Ett, G., Ett., V., 2011. Carbon materials in composite bipolar plates for polymer electrolyte membrane fuel cells: A review of the main challenges to improve electrical performance. Journal of Power Sources 196 (6), 2945-2961. doi:10.1016/j.jpowsour.2010.12.041.

[123] Xiang, C., Jin, L.L.C., Zhang, S.Y., et al., 2010. Expanded graphite/polyaniline electrical conducting composite - Synthesis, conductive and dielectric properties Materials Letters 64 (11), 1313-1315.

[124] Papageorgiou, D.G., Kinloch, I.A., Young, R.J., 2017. Mechanical properties of graphene and graphene based nano composites. Progress in Material Science 90, $75-125$

[125] Gadipelli, S., Guo, Z.X., 2015. Graphene-based materials synthesis and gas sorption storage and separation. Progress in Material Science 69, 1-60.

[126] Taherian, R., Hadianfard, M.J., Nazad, A., 2013. A new equation for predicting electrical conductivity of carbon-filled polymer composites used for bipolar plates of fuel cells. Journal of Applied Polymer Science 128 (3), 1497-1509.

[127] Murdie, N., 1997. Carbon fiber/carbon composites: Production, properties, and applications. In: Marsh, H., Heintz, E.A., Rodríguez-Reinoso, F. (Eds.), Introduction to Carbon Technologies, Secretariado do Publicaciones. Spain: University of Alicante.

[128] Wang, C., Astruc, D., 2018. Recent development of metallic nano particle graphene nanocatalysts. Progress in Material Science 94, $306-386$.

[129] Priyanka, H., Maheshwari, R.B., Mathur, R.B., Dhami, T.L., 2007. Fabrication of high strength and a low weight composite bipolar plate for fuel cell applications. Journal of Power Sources 173 (1), 394-403. doi:10.1016/j.jpowsour.2007.04.049.

[130] Yang, T., Shi, P., 2008. Study on the mesocarbon microbeads/polyphenylene sulfide composite bipolar plates applied for proton exchange membrane fuel cells. Journal of Power Sources 175 (1), 390-396. doi:10.1016/j.jpowsour.2007.08.113.

[131] Kim, J.W., Kim, N.H., Kuilla, T., et al., 2010. Synergy effects of hybrid carbon system on properties of composite bipolar plates for fuel cells. Journal of Power Sources 195 (17), 5474-5480. doi:10.1016/j.jpowsour.2010.03.083.

[132] Zhang, G., Sun, S., Yang, D., Dodelet, J.-P., Sacher, E., 2008. The surface analytical characterization of carbon fibers functionalized by $\mathrm{H}_{2} \mathrm{SO}_{4} / \mathrm{HNO}_{3}$ treatment. Carbon 46 (2), 196-205. doi:10.1016/j.carbon.2007.11.002.

[133] Taipalus, R., Harmia, T., Zhang, M.Q., Friedrich, K., 2001. The electrical conductivity of carbon-fibre-reinforced polypropylene/polyaniline complex-blends: Experimental characterisation and modelling. Composites Science and Technology 61 (6), 801-814.

[134] Donnet, J.B., Custodero, E., Wang, T.K., 1996. Atomic force microscopy of carbon black aggregates. Kautschuk Gummi Kunststoffe 49 (4), $274-279$.

[135] Ma, P.-C., Siddiqui, N.A., Gad, M., Kim, J.-K., 2010. Dispersion and functionalization of carbon nanotubes for polymer-based nanocomposites: A review. Composites PART A-Applied Science and Manufacturing 41 (10), 1345-1367. ISSN: 1359 - 835X.

[136] Saito, S., Zettl, A., 2008. Chapter 1 nanotubes: An experimental overview. In: Carbon Nanotubes quantum cylinders of graphene. (eBook ISBN: 9780080569918, Hardcover ISBN: 9780444532763).

[137] Dhakate, S.R., Sharma, S., Chauhan, N., Seth, R.K., Mathur, R.B., 2010. CNTs nanostructuring effect on the properties of graphite composite bipolar plate. International Journal of Hydrogen Energy 35 (9), 4195-4200. doi:10.1016/j.ijhydene.2010.02.072.

[138] Hsiao, M.-C., Liao, S.-H., Yen, M.-Y., et al., 2010. Effect of graphite sizes and carbon nanotubes content on flowability of bulk-molding compound and formability of the composite bipolar plate for fuel cell. Journal of Power Sources 195 (17), 5645-5650. doi:10.1016/j.jpowsour.2010.03.065

[139] Oliveira, M.C.L., Et, G., Antunes, R.A., 2013. Corrosion and thermal stability of multi-walled carbon nanotube-graphite-acrylonitrile-butadiene-styrene composite bipolar plates for polymer electrolyte membrane fuel cells. Journal of Power Sources 221, 345-355. doi:10.1016/j.jpowsour.2012.08.052.

[140] Kuilla, T., Bhadra, S., Yao, D., et al., 2010. Recent advances in graphene based polymer composites. Progress in Polymer Science 35 (11), 1350-1375. doi:10.1016/]. progpolymsci.2010.07.005.

[141] Dreyer, D.R., Park, S., Bielawski, C.W., Ruoff, R.S., 2010. The chemistry of graphene oxide. (Critical Review) Chemical Society Reviews 39, $228-240$.

[142] Wang, G., Yang, J., Park, J., et al., 2008. Facile synthesis and characterization of graphene nanosheets. Journal of Physical Chemistry C 112 (22), $8192-8195$. doi:10.1021/jp710931h.

[143] Wang, G., Shen, X., Wang, B., Yao, J., Park, J., 2009. Synthesis and characterisation of hydrophilic and organophilic graphene nanosheets. Carbon 47 (5), $1359-1364$. doi:10.1016/..carbon.2009.01.027.

[144] Li, X., Wang, X., Zhang, Li., Lee, S., Dai, H., 2009. Chemically derived, Ultrasmooth graphene nanoribbons semiconductors. Sciences 319 (5867), $1229-1232$. doi:10.1126/science.1150878.

[145] Blake, P., Brimicombe, P.D., Nair, R.R., et al., 2008. Graphene based liquid crystal device. Nano Letters 8 (6), 1704-1708. doi:10.1021/nl080649i.

[146] Kakati, B.K., Ghosh, A., Verma, A., 2013. Efficient composite bipolar plate reinforced with carbon fiber and graphene for proton exchange membrane fuel cell. International Journal of Hydrogen Energy 38 (22), 9362-9369.

[147] Hamilton, P.J., Pollet, B.G., 2010. Polymer electrolyte membrane fuel cell (PEMFC) flow field plate: Design, materials and characterisation. Fuel Cells 10 (4), 489-509.

[148] Radhakrishnan, S., Ramanujam, B.T.S., Adhikari, A., Sivaram, S., 2007. High-temperature, polymer-graphite hybrid composites for bipolar plates: Effect of processing conditions on electrical properties. Journal of Power Sources 163 (2), 702-707. doi:10.1016/j.jpowsour.2006.08.019.

[149] Yin, Q., Li, A.-J., Wang, W.-Q., Xia, L.-G., Wang, Y.-M., 2007. Study on the electrical and mechanical properties of phenol formaldehyde resin/graphite composite for bipolar plate. Journal of Power Sources 165 (2), 717-721. doi:10.1016/j.jpowsour.2006.12.019.

[150] Yin, Q., Sun, K.-N., Li, A.-J., et al., 2008. Study on carbon nanotube reinforced phenol formaldehyde resin/graphite composite for bipolar plate. Journal of Power Sources 175 (2), 861-865. doi:10.1016/j.jpowsour.2007.10.013.

[151] Kinumoto, T., Nagano, K., Tsumura, T., Toyoda, M., 2010. Thermal and electrochemical durability of carbonaceous composites used as a bipolar plate of proton exchange membrane fuel cell. Journal of Power Sources 195 (19), 6473-6477. doi:10.1016/i.jpowsour.2010.04.045.

[152] André, J., Antoni, L., Petit, J.P., 2010. Corrosion resistance of stainless steel bipolar plates in a PEFC environment: A comprehensive study. International Journal of Hydrogen Energy 35 (8), 3684-3697. doi:10.1016/j.ijhydene.2010.01.062.

[153] Hung, Y., Tawfik, H., Mahajan, D., 2009. Durability and characterization studies of polymer electrolyte membrane fuel cell's coated aluminum bipolar plates and membrane electrode assembly. Journal of Power Sources 186 (1), 123-127. doi:10.1016/j.jpowsour.2008.09.079.

[154] Antunes, R.A., Oliveira, M.C.L., Ett, G., Ett, V., 2010. Corrosion of metal bipolar plates for PEM fuel cells: A review. International Journal of Hydrogen Energy 35 (8), 3632-3647. doi:10.1016/j.ijhydene.2010.01.059.

[155] Nikiforov, A.V., Petrushina, I.M., Christensen, E., Tomás-García, A.L., Bjerrum, N.J., 2011. Corrosion behaviour of construction materials for high temperature steam electrolysers. International Journal of Hydrogen Energy 36 (1), 111-119. doi:10.1016/j.ijhydene.2010.09.023.

[156] Turner, J.A., Wang, H., Brady, M.P., 2005. Corrosion protection of metallic bipolar plates for fuel cells. In: DOE Hydrogen Program Review. USA: National Renewable Energy Laboratory

[157] Yang, Y., Guo, L.-J., Liu, H., 2011. Corrosion characteristics of SS316L as bipolar plate material in PEMFC cathode environments with different acidities. International Journal of Hydrogen Energy 36 (2), 1654-1663. doi:10.1016/j.i.jhydene.2010.10.067. 
[158] Feng, K., Cai, X., Sun, H., Li, Z., Paul, K.C., 2010. Carbon coated stainless steel bipolar plates in polymer electrolyte membrane fuel cells. Diamond and Related Materials 19 (11), 1354-1361. doi:10.1016/j.diamond.2010.07.003.

[159] Chung, C.-Y., Chen, S.-K., Chiu, P.-J., et al., 2008. Carbon film-coated 304 stainless steel as PEMFC bipolar plate. Journal of Power Sources 176 (1), $276-281$. doi:10.1016/j.jpowsour.2007.10.022.

[160] Marsh, H., Warburton, A.P., 1970. Catalysis of graphitization. Journal of Applied Chemistry 20 (4), 133-142. doi:10.1002/jctb.5010200409.

[161] Wu, B., Lin, G., Fu, Y., Hou, M., Yi, B., 2010. Chromium-containing carbon film on stainless steel as bipolar plates for proton exchange membrane fuel cells. International Journal of Hydrogen Energy 35 (24), 13255. doi:10.1016/j.jhydene.2010.09.036.

[162] Wang, H., Brady, M.P., More, K.L., Meyerlll, H.M., Turner, J.A., 2004. Thermally nitrided stainless steels for polymer electrolyte membrane fuel cell bipolar plates: Part 2: Beneficial modification of passive layer on AISI446. Journal of Power Sources 138 (1-2), 79-85. doi:10.1016/j.jpowsour.2004.06.064.

[163] Brady, M.P., Wang, H., Yang, B., et al., 2007. Growth of Cr-nitrides on commercial Ni-Cr and Fe-Cr base alloys to protect PEMFC bipolar plates. International Journal of Hydrogen Energy 32 (16), 3778-3788. doi:10.1016/j.jijhydene.2006.08.044.

[164] Park, C.Y., Lee, T.H., Dorris, S.E., Balachandran, U., 2013. A cobalt-free oxygen transport membrane, $\mathrm{BaFe}_{0.9} \mathrm{Zr}_{0.1} \mathrm{O}_{3-\delta}$, and its application for producing hydrogen. International Journal of Hydrogen Energy 38 (15), 6450-6459. do::10.1016/i.jihydene.2013.02.119.

[165] Yang, B., Brady, M.P., Wang, H., et al., 2007. Protective nitride formation on stainless steel alloys for proton exchange membrane fuel cell bipolar plates. Journal of Power Sources 174 (1), 228-236. doi:10.1016/j.jpowsour.2007.08.106.

[166] Zhang, Z.L., Bell, T., 1985. Structure and corrosion resistance of plasma nitride stainless steel. Surface Engineering 1 (2), 131-136

[167] Cha, B.-C., You, Y.-Z., Hong, S.-T., et al., 2011. Nitride films as protective layers for metallic bipolar plates of polymer electrolyte membrane fuel cell stacks. International Journal of Hydrogen Energy 36 (7), 4565-4572.

[168] Brady, M.P., Yang, B., More, K.L., et al., 2006. Cost-Effective Surface Modification For Metallic Bipolar Plates, Oak ridge National Laboratory, 2005. Fuel Cell Tech Team Meeting. USCAR facility. Southfield, MI.

[169] Davies, D.P., Adcock, P.L., Turpin, M., Rowen, S.J., 2000. Stainless steel as a bipolar plate material for solid polymer fuel cells. Journal of Power Sources 86 (1-2), 237-242. doi:10.1016/S0378-7753(99)00524-8.

[170] Davies, D.P., Adcock, P.L., Turpin, M., Rowen, S.J., 2000. Bipolar plate materials for solid polymer fuel cells. Journal of Applied Electrochemistry 30, 101-105. doi:10.1023/A:1003831406406.

[171] Wang, H., Sweikart, M.A., Turner, J.A., 2003. Stainless steel as bipolar plate material for polymer electrolyte membrane fuel cells. Journal of Power Sources 115 (2), 243-251. doi:10.1016/S0378-7753(03)00023-5.

[172] Wang, H., Turner, J.A., 2004. Ferritic stainless steels as bipolar plate material for polymer electrolyte membrane fuel cells. Journal of Power Sources 128 (2), $193-200$. doi:10.1016/j.jpowsour.2003.09.075.

[173] Woodman, A., Anderson, E., Jayne, K., Kimble, M., 1999. Development of corrosion resistant coatings for fuel cellbipolar plate. Physical Science Inc. Home Page. www. psicorp.com/html/pubs/Subjects/FuelCell.htm.

[174] Wind, J., Spah, R., Kaiser, W., Bohm, G., 2002. Metallic bipolar plates for PEM fuel cells. Journal of Power Sources 105 (2), 256-260. doi:10.1016/S0378-7753(01)00950-8.

[175] Lee, S.-J., Huang, C.-H., Lai, J.-J., Chen, Yu-P., 2004. Corrosion-resistant component for PEM fuel cells. Journal of Power Sources 131 (1-2), 162-168. doi:10.1016/I. jpowsour.2004.01.008.

[176] Brady, M.P., Weisbrod, K., Paulauskas, I., et al., 2004. Preferential thermal nitridation to form pin-hole free Cr-nitrides to protect proton exchange membrane fuel cell metallic bipolar plates. Nucleic Acids Res 50 (7), 1017-1022. https://doi.org/10.1016/.scriptamat.2003.12.028.

[177] Zafar, I., Guiheen, J., Dave, N.. Timothy, R., 2001. World Patent W000 128019.

[178] Matsumoto T., Niikura J., Ohara H., et al., 2001. Solid polymer electrolyte fuel cell. European Patent EP 1094535.

[179] Lawrence, R., 1980. Low cost bipolar current collector - Separator for electrochemical cells. US Patent 4214969

[180] Balko, E., Lawrence, R., 1982. Carbon fibre reinforced fluorocarbon graphite bipolar current collector separator. US Patent 4339322.

[181] Ledjeff-Hey, K., Mahlendorf, F., Neimzig, O., Trutmann, A., Mercator, G., 1988. In: Proceedings of the Fuel Cell. p. 570.

[182] Pellegri, A., Spaziante, P., 1980. Bipolar separator for electrochemical cells and method of preparation thereof. US Patent 4197178.

[183] Emanuelson, R., Luoma W., Taylor W., 1981. Separator plate for electrochemical cells. US Patent 4301222.

[184] Taylor, W., 1986. Coke and graphite filled separator plate for electrochemical cells. US Patent 4592968.

[185] Stewart, Jr., Robert, C., 1987. Carbon - Graphite component for an electrochemical cell and method for making the component. US Patent 4670300.

[186] Umera, T., Murakami, S., 1988. Method for producing carbon sheet and a fuel cell separator. US Patent 4737421.

[187] Besmann, T.M., Klett, J.W., Burchell, T.D., 1997. Carbon composite for a PEM fuel cell. Materials Research Society Symposia Proceedings 496, 243.

[188] Busick D., Wilson M., 2001. Composite Bipolar plate for Electrochemical Cells. US Patent 6248467.

[189] Dong, H., Qi, P.-Y., Li, X., Llewellyn, R., 2006. Improving the erosion - Corrosion resistance of AISI 316 austenitic stainless steel by low-temperature plasma surface alloying with $\mathrm{N}$ and $\mathrm{C}$. Materials Science and Engineering A 431, 137-145.

[190] Cho, E.A., Jeon, U.-S., Ha, H.Y., Hong, S.-A., Oh, I.-H., 2004. Characteristics of composite bipolar plates for polymer electrolyte membrane fuel cells. Journal of Power Sources 125 (2), 178-182. doi:10.1016/j.jpowsour.2003.08.039.

[191] Heinzel, A., Mahlendorf, F., Neimzig, 0., Kreuz, C., 2004. Injection moulded low cost bipolar plates for PEM fuel cells. Journal of Power Sources 131 (1-2), 35-40. doi:10.1016/j.jpowsour.2004.01.014.

[192] Kuan, H.-C., Ma, C.-C.M., Chen, K.H., Chen, S.-M., 2004. Preparation, electrical, mechanical and thermal properties of composite bipolar plate for a fuel cell. Journal of Power Sources 134 (1), 7-17. doi:10.1016/j.jpowsour.2004.02.024.

[193] Feng, K., Shen, Y., Sun, H., et al., 2009. Conductive amorphous carbon-coated 316L stainless steel as bipolar plates in polymer electrolyte membrane fuel cells. International Journal of Hydrogen Energy 34 (16), 6771-6777. doi:10.1016/j.ijhydene.2009.06.030.

[194] Feng, K., Li, Z., Cai, X., Chu, P.K., 2010. Corrosion behavior and electrical conductivity of niobium implanted 316L stainless steel used as bipolar plates in polymer electrolyte membrane fuel cells. Surface and Coatings Technology 205 (1), 85-91. doi:10.1016/i.surfcoat.2010.06.009.

[195] Lavigne, O., Alemany-Dumont, C., Normand, B., Delichère, P., Descamps, A., 2010. Cerium insertion in 316L passive film: Effect on conductivity and corrosion resistance performances of metallic bipolar plates for PEM fuel cell application. Surface and Coatings Technology 205 (7), 1870-1877. doi:10.1016/j.surfcoat.2010.08.051.

[196] Mishra, A.K., Balasubramaniam, R., 2007. Corrosion inhibition of aluminum alloy AA 2014 by rare earth chlorides. Corrosion Science 49 (3), 1027-1044. doi:10.1016/]. corsci.2006.06.026.

[197] Abreu, C.M., Cristóbal, M.J., Nóvoa, X.R., Pena, G., Pérez, M.C., 2002. Characterisation of the electrochemical behaviour of cerium implanted stainless steels. Electrochimica Acta 47 (13-14), 2215-2222. doi:10.1016/S0013-4686(02)00058-0.

[198] Barranco, J., Barreras, F., Lozano, A., et al., 2010.Cr and Zr/Cr nitride CAE-PVD coated aluminum bipolar plates forpolymer electrolyte membrane fuel cells. International Journal of Hydrogen Energy 35 (20), 11489-11498. doi:10.1016/j.ijhydene.2010.05.050.

[199] Lee, C.-H., Lee, Y.-B., Kim, K-M., Jeong, M.-G., Lim, D.-S., 2013. Electrically conductive polymer composite coating on aluminum for PEM fuel cells bipolar plate. Renewable Energy 54, 46-50. doi:10.1016/j.renene.2012.08.071.

[200] Mawdsley, J.R., Carter, J.D., Niyogi, S., et al., 2013. Composite-coated aluminum bipolar plates for PEM fuel cells. Journal of Power Sources 231, $106-112$. doi:10.1016/j.jpowsour.2012.12.074.

[201] Husby, H., 2013. Carbon Based Coatings for Metallic Bipolar Plates in PEM Fuel Cells. Norwegian University of Science and Technology, Department of Materials Science and Engineering. 